\title{
Mid-crustal storage and crystallization of Eyjafjallajokull ankaramites, South Iceland
}

\section{Nikkola, Paavo}

2019

Nikkola , P , Bali , E , Kahl , M , van der Meer , Q H A , Ramo , O T, Gudfinnsson , G H \& Thordarson , T 2019 , ' Mid-crustal storage and crystallization of Eyjafjallajokull ankaramites, South Iceland ' , Jokull , vol. 69 , pp. 83-102 . https://doi.org/10.33799/jokull2019.69.083

http://hdl.handle.net/10138/318278

https://doi.org/10.33799/jokull2019.69.083

unspecified

Downloaded from Helda, University of Helsinki institutional repository.

This is an electronic reprint of the original article.

This reprint may differ from the original in pagination and typographic detail.

Please cite the original version. 


\title{
Mid-crustal storage and crystallization of Eyjafjallajökull ankaramites, South Iceland
}

\author{
Paavo Nikkola ${ }^{1,2, *}$, Enikő Bali ${ }^{2,3}$, Maren $\mathrm{Kahl}^{4}$, Quinten H. A. van der Meer ${ }^{2}$, \\ O. Tapani Rämö ${ }^{1}$, Guðmundur H. Guðfinnsson ${ }^{2}$, and Thorvaldur Thordarson ${ }^{3}$ \\ ${ }^{1}$ Department of Geosciences and Geography, Geology and Geophysics Research Group, \\ P.O. Box 64, FI-00014 University of Helsinki, Finland \\ ${ }^{2}$ Nordic Volcanological Center, Institute of Earth Sciences, University of Iceland, Sturlugata 7, 101 Reykjavík, Iceland \\ ${ }^{3}$ Faculty of Earth Sciences, University of Iceland, Sturlugata 7, 101 Reykjavík, Iceland \\ ${ }^{4}$ Institut für Geowissenschaften, Universität Heidelberg, Im Neuenheimer Feld 234-236, 69120 Heidelberg, Germany \\ ${ }^{*}$ Correspondence: paavo.nikkola@helsinki.fi
}

\begin{abstract}
Our understanding of the long-term intrusive and eruptive behaviour of volcanic systems is hampered by a relatively short period of direct observation. To probe the conditions of crustal magma storage below South Iceland, we have analysed compositions of minerals, mineral zoning patterns, and melt inclusions from two Eyjafjallajökull ankaramites located at Brattaskjól and Hvammsmúli. These two units are rich in compositionally diverse macrocrysts, including the most magnesian olivine (Fo $\left.{ }_{88-90}\right)$ and clinopyroxene $\left(M \#_{c p x} 89.8\right)$ known from Eyjafjallajökull. Olivine-hosted spinel inclusions have high $\mathrm{Cr}_{\text {spl }}$ (52-80) and $\mathrm{TiO}_{2}\left(1-3 \mathrm{wt}^{2}\right)$ and low $\mathrm{Al}_{2} \mathrm{O}_{3}(8-22 \mathrm{wt} \%)$ compared to typical Icelandic chromian spinel. The spinel-olivine oxybarometer implies a moderate oxygen fugacity of $\triangle \log F M Q 0-0.5$ at the time of crystallization, and clinopyroxene-liquid thermobarometry crystallization at mid-crustal pressures (1.7-4.2 kbar, 3.0 $1.4 \mathrm{kbar}$ on average) at 1120$1195^{\circ} \mathrm{C}$. Liquid-only thermometry for melt inclusions with $\mathrm{Mg \#}_{\text {melt }}$ 56.1-68.5 and olivine-liquid thermometry for olivine macrocrysts with $\mathrm{Fo}_{80.7-88.9}$ yield crystallization temperatures of $1155-1222^{\circ} \mathrm{C}$ and $1136-1213^{\circ} \mathrm{C}$, respectively. Diffusion modelling of compositional zonations in the Brattaskjól olivine grains imply that the Brattaskjól macrocrysts were mobilized and transported to the surface from their mid-crustal storage within a few weeks (at most in 9-37 days). Trends in clinopyroxene macrocryst compositions and the scarcity of plagioclase indicate that the mid-crustal cotectic assemblage was olivine and clinopyroxene, with plagioclase joining the fractionating mineral assemblage later. In all, the crystal cargoes in the Brattaskjól and Hvammsmúli ankaramites are composed of agitated wehrlitic or plagioclase wehrlitic crystal mushes that crystallized over a large temperature interval at mid-crustal depths.
\end{abstract}

\section{INTRODUCTION}

In South Iceland, at the southern tip of the Eastern Volcanic Zone (SEVZ), magmatism occurs outside the main zone of plate spreading in three volcanic systems: Eyjafjallajökull, Katla, and Vestmannaeyjar. The SEVZ is the most recently activated volcanic zone in Iceland (younger than $3 \mathrm{Ma}$; Martin et al., 2011), where mantle-derived magmas intrude relatively cold oceanic crust (Flóvenz and Saemundsson, 1993). Magma batches fractionate comparatively fast under these conditions, as indicated by U-series disequilibria (Sigmarsson, 1996) and the absence of equilibrium phenocryst assemblages (Mattsson and Oskarsson, 2005) in erupted lavas. In Vestmannaeyjar, the mantle-derived melts have been envisioned to evolve in the crust in isolated, small magma reservoirs over a large depth range (Furman et al., 1991; Mattsson and Oskarsson, 2005). Seismic, geodetic and petrogenetic studies of the Eyjafjallajökull 2010 eruption have highlighted a multi-tier volcanic plumb-

JÖKULL No. 69, 2019 
ing system beneath the volcano, and near-direct vertical magma transport from mantle depths (Sigmundsson et al., 2010; Sigmarsson et al., 2011; Keiding and Sigmarsson, 2012; Tarasewicz et al., 2012a,b; Laeger et al., 2017).

Regardless of the advances above, our understanding of crustal storage and evolution of magmas in SEVZ is inadequate, with our best inferences relying on the 2010 Eyjafjallajökull eruption alone. Analysis of minerals with pressure- and temperature-sensitive compositions offers a way forward, as it allows us to make inferences on the conditions of magma differentiation in the SEVZ crust. In this paper, we present major element data on olivine, clinopyroxene, spinel, and melt inclusions from the most primitive Eyjafjallajökull volcanic units: the Brattaskjól and Hvammsmúli ankaramites. We show that these two ankaramites host primitive olivine and clinopyroxene macrocrysts as well as chromian spinel that is the most $\mathrm{Cr}$ - and Ti-rich reported from Iceland. On the basis of thermobarometric calculations and diffusion modelling, we suggest that these crystals were derived from agitated and disaggregated mid-crustal (10.7 \pm 5 $\mathrm{km}$ ) wehrlitic or plagioclase wehrlitic crystal mushes and that they ascended from these depths in a carrier magma within a few weeks only.

\section{EYJAFJALLAJÖKULL VOLCANIC SYSTEM}

Eyjafjallajökull (Figure 1) is a glacier-covered, moderately active volcano that has acted as a locus of magmatism for over $0.78 \mathrm{Ma}$ (Kristjánsson et al., 1988). Typical of off-rift volcanic systems in Iceland, Eyjafjallajökull magmas are enriched in $\mathrm{K}_{2} \mathrm{O}$ and $\mathrm{Na}_{2} \mathrm{O}$ compared to axial rift magmas (Jakobsson, 1972; Hémond et al., 1993) and show trace element and isotopic signatures of "enriched" mantle source (e.g., elevated ${ }^{206} \mathrm{~Pb} /{ }^{204} \mathrm{~Pb}$ in comparison to MORB) (Peate et al., 2010). These characteristics are most often attributed to low-degree melting of incompatible trace element rich and mineralogically distinct mantle source compared to the depleted source of common MORB (Chauvel and Hémond, 2000; Kokfelt et al., 2006).
Observations of the Eyjafjallajökull 2010 eruption build a strong case for a trans-crustal magma plumbing system beneath the volcano, with defined magma intrusions in the brittle upper crust $(<10-12 \mathrm{~km}$ depth, Hjaltadóttir et al. 2009) underlain by poorly constrained magma storage zones in ductile crust and upper mantle (Sigmundsson et al., 2010; Sigmarsson et al., 2011; Keiding and Sigmarsson, 2012; Tarasewicz et al., 2012a, b). Although Eyjafjallajökull has a shallow silicic magma intrusion at $5 \mathrm{~km}$ depth (Sigmarsson et al., 2011), and intrusions of magma into the shallow crust (e.g., $5 \mathrm{~km}$ beneath the eastern flank of the volcano; Sigmundsson et al., 2010) predated the eruption, the Eyjafjallajökull 2010 eruption was fed by magma from considerable depths. During the first weeks of the eruption, seismicity was focused on the brittle crust $(<10 \mathrm{~km})$, suggesting a mid-crustal magma source. However, later a downward propagation of earthquakes down to $\sim 30 \mathrm{~km}$ below the surface was detected, with distinct seismic clusters at depths of $\sim 19 \mathrm{~km}$ and $\sim 25 \mathrm{~km}$, potentially reflecting depressurization of two or more $1-10 \mathrm{~km}^{3}$ intrusions at these depths (Tarasewicz et al., 2012b, a). This suggests that the eruption tapped magma from the mantle (from depths greater than $\sim 22 \mathrm{~km}$; Brandsdóttir and Menke, 2008). Exhaustion of the mid-crustal reservoirs and deep tapping of magmas supports views of SEVZ as an embryonic rift segment (e.g., Mattsson and Oskarsson, 2005), where crustal magma storage zones are still small and maybe ephemeral (Sigmarsson, 1996) in comparison to active rift zones with hotter crust (Flóvenz and Saemundsson, 1993) and presumably larger crustal magma reservoirs.

\section{SAMPLES}

The volcanic units sampled for this study, Brattaskjól and Hvammsmúli (Figure 1), are the most primitive volcanic units of the Eyjafjallajökull volcano described so far (Loughlin, 1995). Both are partly eroded outcrops on the southern slope of Eyjafjallajökull and seemingly subaerial in character (Loughlin, 1995), although a shallow intrusive origin for Hvammsmúli has also been suggested (Steinthórsson, 1964). We follow the established practise (e.g., Steinthórsson, 1964; Loughlin, 1995) and refer to 


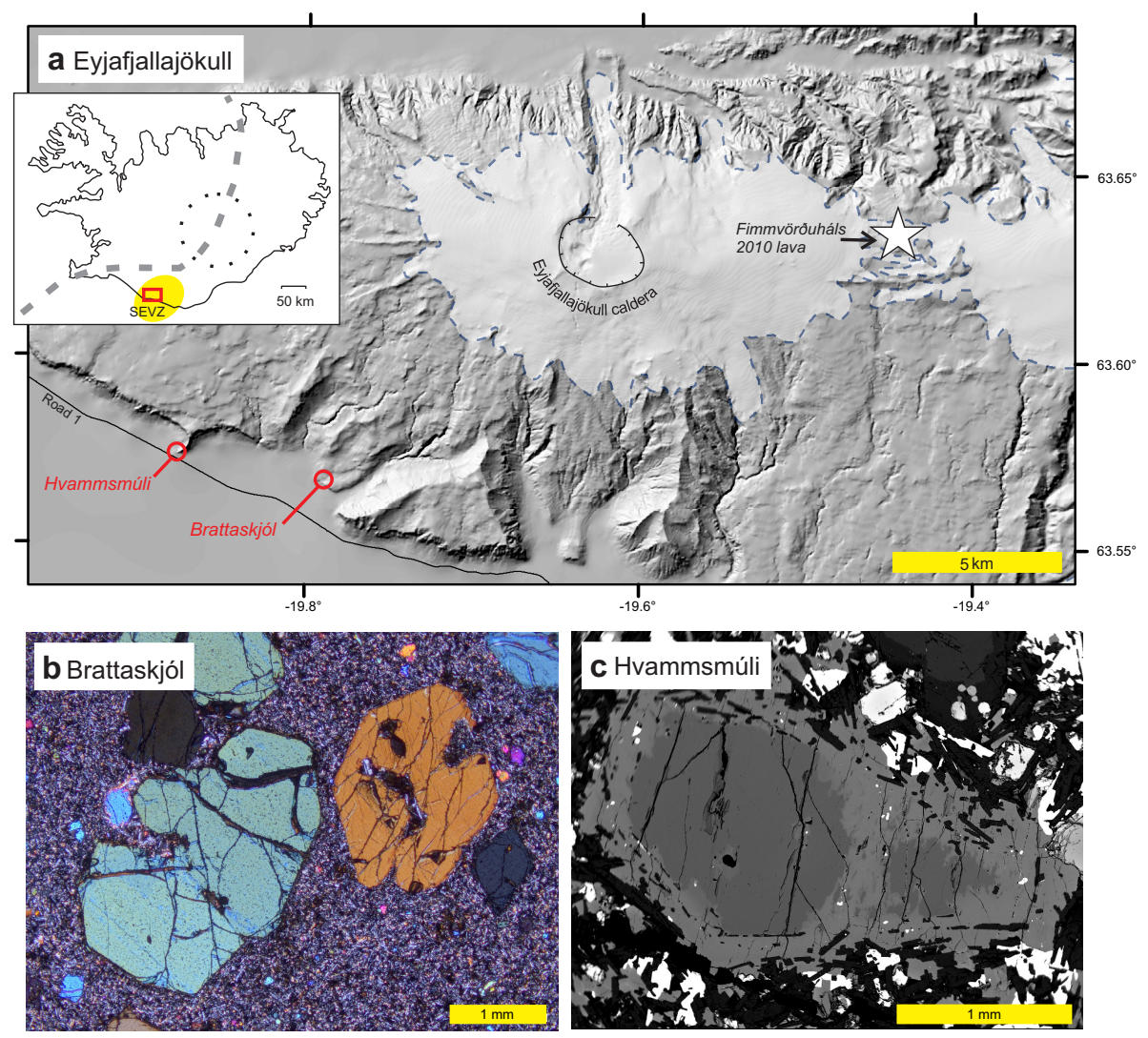

Figure 1. a) Map of the Eyjafjallajökull volcano with sampled locations and the 2010 Fimmvörðuháls lava flow field. Inset shows map location (red rectangle) and the southern tip of the Eastern Volcanic Zone (SEVZ) in yellow. The active plate boundary and the locus of the Iceland mantle plume (Wolfe et al., 1997) are marked with grey and black stippled lines, respectively. b) Photomicrograph (in cross-polarized light) showing the texture of the Brattaskjól ankaramite sample. The large crystal on the left is olivine (3rd order blue interference colour) and the large crystal on the right (1st order orange) is augite. c) Backscattered electron image of an augite crystal in a Hvammsmúli ankaramite sample. - a) Kort af Eyjafjallajökulseldstöðinni sem sýnir sýnastaði og staðsetningu hraunsins sem myndaðist í gosi á Fimmvörðuhálsi árið 2010. Innfellda myndin sýnir staðsetningu kortsins (rauður ferhyrningur) og suðurenda eystra gosbeltisins (SEVZ) með gulum lit. Virku flekamótin eru merkt með gráum strikalínum og útlínur möttulstróksins (Wolfe o.fl., 1997) með svörtum strikalínum. b) Smásjárljósmynd (tvískautað ljós) sem sýnir textúr í ankaramítsýni frá Brattaskjóli. Stóri kristallinn til vinstri er ólivín (blár bylgjuvíxllitur af priðju röð) og stóri kristallinn hagra megin er ágít (gulur litur af fyrstu röð). c) Endurkastsrafeindamynd af ágítkristal í ankaramítsýni frá Hvammsmúla.

these outcrops as ankaramites. These ankaramites are highly porphyritic with abundant $(\sim 30$ vol\%, see Steinthórsson, 1964) olivine and clinopyroxene macrocrysts in near equal amounts. Hvammsmúli also has minor amounts of plagioclase macrocrysts, not observed in Brattaskjól. As macrocrysts, we consider crystals that are $>0.3 \mathrm{~mm}$ in length and precede groundmass minerals. Hvammsmúli has been dated to $587 \pm 31 \mathrm{ka}$ (Wiese, 1992), but the exact age of Brattaskjól is unknown. An age of 500-720 ka for Brattaskjól is probable, however, judging from its stratigraphic position (Loughlin, 1995) and normal magnetic polarity. 
The Brattaskjól olivine and clinopyroxene macrocrysts are often embayed and have thin compositionally zoned rims in contact with fine-grained groundmass mineralogy (Figure 1b). In Hvammsmúli samples, conversely, the groundmass is coarse and olivine and clinopyroxene macrocrysts have broad compositionally zoned rims that commonly enclose groundmass plagioclase near the macrocryst edges (Figure 1c). In addition to the zonation near crystal edges, clinopyroxene macrocrysts in both localities exhibit complex oscillatory and convolute zoning, while sector zoning was not identified.

The Brattaskjól olivine macrocrysts are commonly devoid of spinel and melt inclusions. When present, the Brattaskjól melt inclusions are found in the cores of the crystals as primary or pseudosecondary inclusions (following the nomenclature of Roedder, 1984). Their size varies between 20 and $250 \mu \mathrm{m}$ and they are partially crystallized, containing dominantly clinopyroxene daughter minerals, silicate glass and a large bubble phase. These inclusions may also contain opaque phases, which are generally accidentally trapped spinel crystals. Spinel and melt inclusions are more common in the Hvammsmúli samples, and some Hvammsmúli olivines have small (usually $<1 \mu \mathrm{m}$ ) oxide exsolutions. The textural appearance of melt inclusions is similar to those observed in olivine grains from Brattaskjól. These inclusions contain abundant clinopyroxene, minor orthopyroxene, ilmenite and spinel daughter minerals, a vapour phase and interstitial silicate glass (see Björnsson, 2019). In backscattered electron images, we commonly observe a bright Fe-rich diffusion halo in olivine around the melt inclusions in Hvamsmmúli samples. This halo is missing around Brattaskjól melt inclusions.

\section{ANALYTICAL AND EXPERIMENTAL METHODS}

\section{Melt inclusion homogenization experiments}

As melt inclusions from both localities were partially crystalline, we tried to homogenize them. Handpicked olivine crystals were placed in a graphite crucible and mixed with graphite powder in order to avoid oxidation during the heating experiments. We carried out three sets of experiments at temperatures of 1200 , 1220 and $1240^{\circ} \mathrm{C}$. The precision of the temperature reading, calibrated to the melting points of $\mathrm{Au}, \mathrm{Ag}$ and $\mathrm{NaCl}$, was $\pm 5^{\circ} \mathrm{C}$. Crucibles were placed in the hightemperature oven at the target temperature and kept there for 5 minutes. After 5 minutes, the samples were quenched in room temperature water. Olivine was recovered after quenching and mounted in epoxy. Melt inclusions were exposed by manual polishing and inspected under the polarizing microscope. More than $90 \%$ of the melt inclusions from Brattaskjól were homogenized at $1200 \pm 5^{\circ} \mathrm{C}$, and all of them at $1220^{\circ} \mathrm{C}$. By contrast, a few crystals were observed in Hvammsmúli melt inclusions even after heating to $1240^{\circ} \mathrm{C}$.

\section{Electron microprobe analysis}

We separated olivine and clinopyroxene macrocrysts from crushed and sieved $(\varnothing=0.1-4.0 \mathrm{~mm})$ rock samples and determined their major and minor element compositions using a JEOL JXA-8230 electron microprobe at the University of Iceland. Clinopyroxene was analysed in a thin section made from the Hvammsmúli sample. In total, we analysed 192 olivine and 51 clinopyroxene crystals for their core compositions, 38 spinel and 21 melt inclusions in olivine, and 47 concentration profiles (with $4-10 \mu \mathrm{m}$ spacing between analysis spots) across olivine zonation. Acceleration voltage and a beam current of 15 $\mathrm{keV}$ and $20 \mathrm{nA}$, respectively, were used for analysis of clinopyroxene, spinel and olivine zonation, whereas $10 \mathrm{nA}$ beam current was used for analyses of melt inclusions. For the high-precision trace element analyses of olivine cores, we used a modified version of the analysis protocol by Batanova et al. (2015) with acceleration voltage of $20 \mathrm{keV}$ and a high beam current of $500 \mathrm{nA}$ (see Nikkola et al., 2019; for details). Crystals of known composition were analysed to check for instrumental drift. The mineral and melt compositions are available from the authors on request.

\section{EBSD analysis}

Crystallographic orientations of olivine macrocrysts were resolved with electron backscatter diffraction (EBSD, Prior et al., 1999) using FEI Quanta SEM at the University of Leeds (UK). The EBSD analyses were performed to constrain the crystallographic 
directions with respect to the micro-analytical traverses. This is essential for diffusion modelling of olivine, as the diffusivity of elements (e.g., Fe-Mg or $\mathrm{Ni}$ ) in olivine is anisotropic, with diffusion along the crystallographic c-axis being six times faster than along the a- or b-axes (e.g. Dohmen and Chakraborty, 2007; Dohmen et al., 2007). Following the procedure of Kahl et al. (2017), we acquired orientation maps consisting of hundreds of EBSD point determinations for a total of 46 olivine grains from Brattaskjól and Hvammsmúli. We used the HKL CHANNEL 5 EBSD post-processing software to extract hundreds of orientation measurements from individual crystals. The EBSD Euler angles were converted into plunges and trends of the a-, b- and c-axes of the analysed olivines using an Excel sheet provided by Dr. D. Morgan (University of Leeds). Finally, the angular relations between the crystals a-, b- and c-directions and the micro-analytical traverses were acquired using the Stereo32 software developed at the Ruhr-Universität Bochum.

\section{MINERAL AND MELT COMPOSITIONS}

\section{Olivine}

The Brattaskjól and Hvammsmúli olivine macrocryst cores show substantial, yet similar, compositional variability in terms of Fo $\left(\mathrm{Fo}_{81-90}\right)$ and minor elements (e.g., Ni, Figure 2a). Both have a population of $\mathrm{Fo}_{88-90}$ olivine cores showing a large minor element variability ( $\mathrm{Ni}, \mathrm{Mn}, \mathrm{Ca})$. Minor element variation in $\mathrm{Fo}_{<86}$ olivine cores, at a given Fo content, is less pronounced (see Nikkola et al., 2019).

All Brattaskjól olivine macrocrysts $(\mathrm{n}=22)$ analysed for their compositional zonation have thin $(<100 \mu \mathrm{m})$ Fe-Mg zonation around homogenous cores. Interestingly, olivine grains with $\mathrm{Fo}_{>85.7}$ cores $(n=15)$ are normally zoned (Fo decreases towards crystal edges), whereas olivine grains with $\mathrm{Fo}_{<84.4}$ cores have complex reverse zoned rims ( $\mathrm{n}=7$, high-Fo bands near crystal edges, Figure 2d).

The Fo zonation in normally zoned Brattaskjól olivines exhibits changes in slope (Figure 2b) and steps (Figure 2c), and as such does not follow the steady decrease in Fo towards crystal boundaries typical of diffusion under steady-state conditions (Costa et al., 2008). The outermost parts of the olivine crystals have the steepest decrease in Fo (B1 and C1 in Figure $2 \mathrm{~b}$ and $2 \mathrm{c}$ ), followed by an inner rim section with a shallower gradient in the change of Fo (B2 and $\mathrm{C} 2$ in Figure $2 \mathrm{~b}$ and $2 \mathrm{c}$ ). These olivine grains also commonly exhibit high-Fo "shoulders", with an approximate composition of $\mathrm{Fo}_{89.2}$, near the outer edges of the otherwise homogenous crystal cores (B3 in Figure $2 \mathrm{~b}$ ). The complexly reverse zoned Brattaskjól olivine crystals with homogenous $\mathrm{Fo}_{80.9-84.4}$ cores have $\sim 10-30 \mu \mathrm{m}$ thick Fo $_{83.1-85.4}$ bands near crystal edges (Figure 2d). The outermost edges of the crystals have the lowest and very variable Fo contents ranging from $\mathrm{Fo}_{73.5}$ to $\mathrm{Fo}_{82.8}$. Typically, the highFo bands near the crystal edges have relatively broad diffuse boundaries towards the crystal interior in comparison to the steep decrease in Fo towards the outer edge of the crystals (Figure 2d).

Unlike the Brattaskjól olivine macrocrysts, all Hvammsmúli olivine macrocrysts show broad (up to $700 \mu \mathrm{m}$ ) normal zoning, irrespective of the Fo content in olivine cores (Figure 2e). Some olivine grains also exhibit a two-fold division in the Fo zoning pattern (Figure 2e). In these olivine crystals, the Fo zonation pattern in the outermost $200 \mu \mathrm{m}$ of the crystal has a concave slope (E1), which is indicative of growthdominated zoning, followed by up to $500 \mu \mathrm{m}$ convex slope (E2), more typical to diffusive re-equilibration.

\section{Spinel inclusions in olivine}

Spinel inclusions in the Brattaskjól $(\mathrm{n}=16)$ and Hvammsmúli olivine macrocrysts $(\mathrm{n}=$ 22) have $\mathrm{Mg \#}_{s p l}\left(\mathrm{Mg \#}_{s p l}=\right.$ cation fraction $\left.100 \mathrm{Mg} /\left(\mathrm{Mg}+\mathrm{Fe}^{2+}\right)\right)$ of $38-66, \mathrm{Cr} \#(\mathrm{Cr} \#=$ cation fraction $100 \mathrm{Cr} /(\mathrm{Cr}+\mathrm{Al}))$ of $52-80, \mathrm{Fe}^{3+} / \mathrm{Fe}_{\text {tot }}$ of $0.15-$ $0.35,1-3 \mathrm{wt} \% \mathrm{TiO}_{2}$, and 8-22 wt $\% \mathrm{Al}_{2} \mathrm{O}_{3}$ (Figure $3)$. The spinel inclusions in Brattaskjól olivine grains have somewhat higher mean $\mathrm{Cr} \#$ and $\mathrm{Fe}^{3+} / \mathrm{Fe}_{t o t}$ than in the Hvammsmúli olivine grains, although their compositions do overlap. In addition, variation in $\mathrm{Al}_{2} \mathrm{O}_{3}$ is less in the Brattaskjól spinels (10-16 wt\% $\mathrm{Al}_{2} \mathrm{O}_{3}$ ). In the Hvammsmúli samples, spinel is also found in olivine-hosted melt inclusions; these have a distinct composition with relatively high ( $>55 \mathrm{wt} \%)$ $\mathrm{Al}_{2} \mathrm{O}_{3}$ (Björnsson, 2019). 
Nikkola et al.
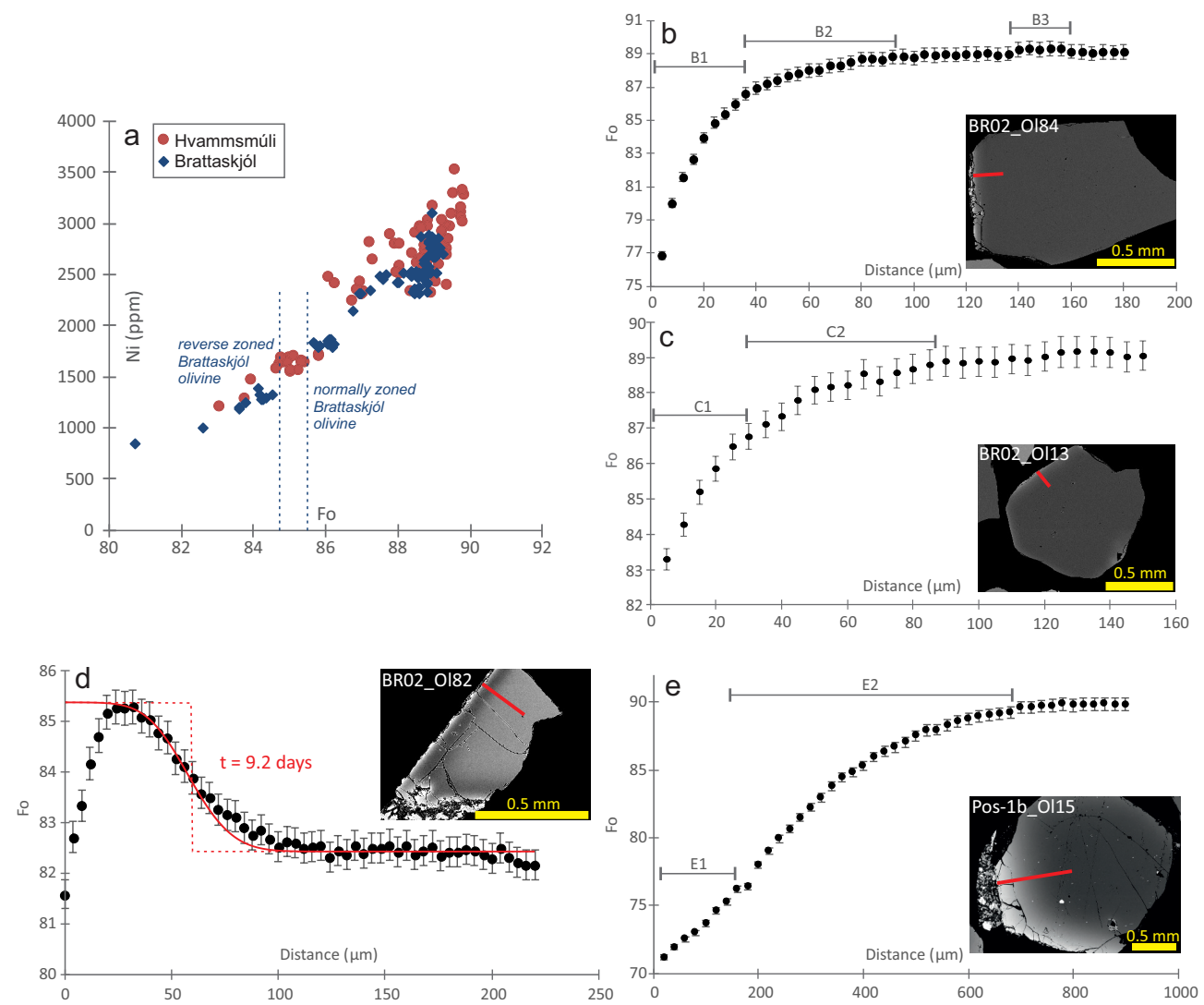

Figure 2. a) $\mathrm{Ni}(\mathrm{ppm})$ vs. forsterite $(\mathrm{Fo}=$ cation fraction $100 \mathrm{Mg} /(\mathrm{Mg}+\mathrm{Fe}))$ plot of Brattaskjól and Hvammsmúli olivine core compositions; data from Nikkola et al. (2019). Brattaskjól olivines with core compositions up to Fo 84.4 have complex reverse zonation, whereas olivines with $\mathrm{Fo}_{>85.7}$ core compositions are always normally zoned. All Hvammsmúli olivines are normally zoned. b-e) Compilation of micro-analytical traverses across compositionally zoned olivine macrocrysts displaying different zoning patterns (e.g., normal vs. complex reverse). Locations of the traverses are shown with red lines in the backscatter electron images. Olivine macrocrysts BR02_O184 (b), BR02_O113 (c) and Pos-1b_O15 (e) are normally zoned with decreasing Fo towards outermost rims. Zonation sections B1, B2, B3, C1, C2, E1 and E2 are discussed in the text. Brattaskjól olivine BR02_Ol82 (d) is complex reverse zoned, with a band of high Fo near the crystal rim in comparison to Fo in the olivine core. Complex reverse zoned olivine grains like these were used for diffusion modelling. The red stippled line is the initial diffusion model and the red curve is the model zonation after 9.2 days of diffusion. - a) $\mathrm{Ni}$ ( $\mathrm{ppm}$ ) sem fall af forsterítinnihaldi $(F o=$ katjónahlutfallið $100 \mathrm{Mg} /(\mathrm{Mg}+\mathrm{Fe}))$ i kjörnum ólivíns frá Brattaskjóli og Hvammsmúla; gögnin eru frá Nikkola o.fl. (2019). Ólivín í Brattaskjóli með kjarnasamsetningu allt up í Fo ${ }_{84,4}$ er með flókna öfuga beltun en ólivín með $\mathrm{Fo}_{>85,7}$ kjarnasamsetningu er alltaf með reglulega beltun (e. normal zoning). Allt ólivín frá Hvammsmúla er með reglulega beltun. b-e) Dami um örgreiningalínur yfir beltaða ólivíndíla með mismunandi gerðir beltunar (p.e. reglulega og flókna öfuga beltun). Staðsetning línanna er gefin til kynna með rauðum línum á rafeindasmásjármyndunum. Ólivíndílarnir BR02_Ol84 (b), BR02_Ol13 (c) og Pos-1b_Ol5 (e) eru með reglulega beltun par sem kjarninn hefur hátt Fo-gildi sem síðan lakkar í átt að kristalrimanum. Í greininni er ratt um pá hluta beltunar sem merktir eru B1, B2, B3, C1, C2, E1 og E2. Ólivín frá Brattaskjóli merkt BR02_Ol82 (d) er með flókna öfuga beltun, par sem belti naest kristalrimanum er með hátt Fo-gildi í samanburði við kjarna kristalsins. Ólivíndílar sem pessi voru notaðir við líkanreikinga á efnasveimi. Brotna rauða línan gefur til kynna efnasamsetningu dílsins við upphaf líkanreikningsins en heila rauða lína sýnir útreiknaða beltun eftir 9,2 daga af efnasveimi. 
Eyjafjallajökull ankaramites, South Iceland
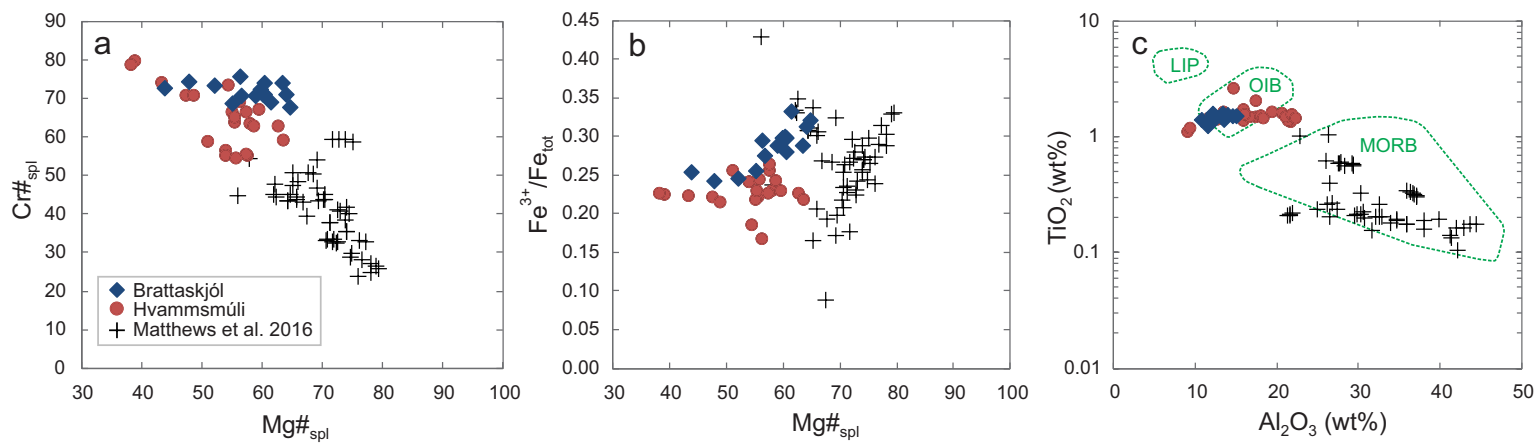

Figure 3. a) $\mathrm{Cr}$ number $\left(\mathrm{Cr} \#_{s p l}=\right.$ cation fraction $\left.100 \mathrm{Cr} /(\mathrm{Cr}+\mathrm{Al})\right)$ against $\mathrm{Mg}$ number $\left(\mathrm{Mg} \#_{s p l}=\right.$ cation fraction $\left.100 \mathrm{Mg} /\left(\mathrm{Mg}+\mathrm{Fe}^{2+}\right)\right)$ in spinel. $2 \sigma$ analytical error is smaller or equal to the symbol size. b) The ratio of ferric iron to total iron $\left(\mathrm{Fe}^{3+} / \mathrm{Fe}_{t o t}\right)$ vs. $\mathrm{Mg} \#$ in spinel. The amount of $\mathrm{Fe}^{3+}$ is calculated based on stoichiometry. c) $\mathrm{Spinel} \mathrm{TiO}_{2}$ vs. $\mathrm{Al}_{2} \mathrm{O}_{3}$ diagram; spinel discrimination fields are after Kamenetsky (2001). Spinel compositions from the Northern Rift

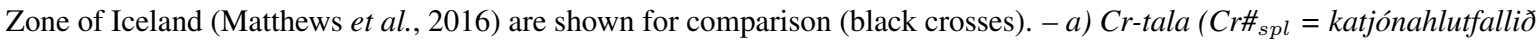
$100 \mathrm{Cr} /(\mathrm{Cr}+\mathrm{Al}))$ sem fall af $\mathrm{Mg}$-tölu $\left(\mathrm{Mg \#} \#_{\text {spl }}=\right.$ katjónahlutfallið $\left.100 \mathrm{Mg} /\left(\mathrm{Mg}+\mathrm{Fe}^{2+} 2\right)\right)$ spínils. $2 \sigma$ óvissa í efnagreiningum er minni eða jafnstór og sýnatáknin. b) Hlutfall ferríjónar af heildarmagni járns $\left(\mathrm{Fe}^{3+} / \mathrm{Fe}_{\text {tot }}\right)$ á móti Mg\# spínils. Magn $\mathrm{Fe}^{3+}$ er reiknað út frá efnaformúlu spínils. c) Styrkur $\mathrm{TiO}_{2}$ á móti styrk $\mathrm{Al}_{2} \mathrm{O}_{3}$ í spínli; aðgreiningarsvaði fyrir spínil eru frá Kamenetsky (2001). Efnasamsetningar spínils frá Norðurgosbelti (Matthews o.fl., 2016) eru sýndar til samanburðar (svartir krossar).

Table 1. Representative melt inclusion (MI) compositions* (in wt\%) from Brattaskjól and Hvammsmúli olivine macrocrysts. All melt inclusions from Brattaskjól reported here were homogenized at $1200^{\circ} \mathrm{C}$. - Damigerðar efnasamsetningar (\% af massa) brádarinnlyksna (MI) í ólivíndílum frá Brattaskjóli og Hvammsmúla. Allar brádarinnlyksur frá Brattaskjóli sem ratt er um í greininni voru gerðar einsleitar með pví að braða par við $1200^{\circ} \mathrm{C}$.

\begin{tabular}{|c|c|c|c|c|c|c|c|c|c|c|c|c|c|c|c|c|}
\hline & $\mathrm{SiO}_{2}$ & $\mathrm{TiO}_{2}$ & $\mathrm{Al}_{2} \mathrm{O}_{3}$ & $\mathrm{FeO}_{\text {tot }}$ & $\mathrm{MnO}$ & $\mathrm{MgO}$ & $\mathrm{CaO}$ & $\mathrm{Na}_{2} \mathrm{O}$ & $\mathrm{K}_{2} \mathrm{O}$ & $\mathrm{P}_{2} \mathrm{O}_{5}$ & $\mathrm{SO}_{3}$ & $\mathrm{Cl}$ & Total & $\mathrm{PEC}^{a}{ }^{a}$ & $\mathrm{Mg} \#^{b}$ & Type $^{d}$ \\
\hline \multicolumn{17}{|l|}{ Brattaskjól } \\
\hline Ol14_mi1_2 & 46.39 & 2.54 & 15.11 & 11.21 & 0.16 & 8.82 & 12.27 & 2.36 & 0.44 & $+\quad 0.30$ & 0.32 & 0.03 & 399.9 & - & 60.9 & 80.9 alk. bas \\
\hline Ol17_mi1 & 46.99 & 2.31 & 16.11 & 9.75 & 0.16 & 7.99 & 13.28 & 2.24 & 0.53 & 0.34 & 0.27 & 0.03 & 3100.0 & - & 61.9 & 82.4 alk. bas \\
\hline Ol10_mi1 & 45.60 & 2.69 & 15.71 & 10.27 & 0.17 & 8.91 & 13.31 & 2.23 & 0.43 & 30.36 & 0.30 & 0.02 & 2100.0 & - & 63.2 & 82.9 alk. bas. \\
\hline Ol7_mil & 46.33 & 2.32 & 15.55 & 9.72 & 0.16 & 9.09 & 12.91 & 2.25 & 0.53 & 30.45 & 0.29 & 0.04 & 499.6 & - & 65.0 & 83.0 alk. bas \\
\hline O125_mi1_2 & 48.02 & 2.07 & 15.25 & 8.27 & 0.12 & 8.87 & 14.19 & 2.29 & 0.44 & 40.28 & 0.25 & 0.02 & 2100.0 & - & 68.0 & 86.0 alk. bas. \\
\hline Ol33_mil & 47.81 & 2.27 & 16.06 & 7.84 & 0.12 & 8.60 & 14.21 & 2.46 & 0.40 & 0.21 & 0.20 & 0.03 & 3100.2 & - & 68.5 & 87.0 alk. bas. \\
\hline Ol11_mil & 49.31 & 2.87 & 13.46 & 7.60 & 0.11 & 9.06 & 13.60 & 2.34 & 0.64 & 0.58 & 0.21 & 0.03 & 399.8 & - & 70.2 & 87.9 ol. tho. \\
\hline Ol1_mi1_2 & 48.58 & 3.56 & 12.97 & 7.29 & 0.15 & 9.96 & 15.79 & 0.89 & 0.18 & 30.24 & 0.03 & 0.00 & 99.6 & - & 73.0 & 88.6 tho. \\
\hline Ol9_mil & 47.27 & 2.44 & 16.29 & 9.56 & 0.17 & 6.25 & 13.28 & 2.68 & 0.53 & 0.32 & - & - & 98.8 & 6.7 & 56.4 & 81.6 alk. bas. \\
\hline O19_mi2_2 & 46.86 & 2.54 & 16.56 & 9.57 & 0.11 & 6.17 & 13.44 & 2.73 & 0.49 & 0.27 & - & - & 98.7 & 9.5 & 56.1 & 81.6 alk. bas. \\
\hline O123_mi2_2 & 51.11 & 2.65 & 15.10 & 6.27 & 0.13 & 6.98 & 14.62 & 2.14 & 0.28 & 30.14 & - & - & 99.4 & 3.9 & 68.8 & \multirow{2}{*}{87.9 tho. } \\
\hline Ol29_mil & 53.91 & 2.31 & 14.69 & 5.86 & 0.15 & 7.46 & 12.88 & 1.76 & 0.38 & 30.06 & - & - & 99.4 & -0.6 & 71.6 & \\
\hline \multicolumn{17}{|l|}{ Hvammsmúli } \\
\hline Ol3_mi1_1160_3 & 49.48 & 2.40 & 14.37 & 6.25 & 0.11 & 7.63 & 11.87 & 3.62 & 0.96 & $5 \quad 1.64$ & 0.10 & 0.06 & 698.5 & not calc. & . 70.7 & \multirow{2}{*}{$\begin{array}{l}79.6 \text { alk. bas } \\
85.6 \text { alk. bas }\end{array}$} \\
\hline Ol1_mi1_1200_1 & 47.94 & 3.35 & 13.71 & 6.18 & 0.09 & 8.38 & 13.86 & 3.26 & 0.76 & 0.52 & 0.07 & 0.04 & 498.2 & not calc. & . 72.9 & \\
\hline
\end{tabular}

JÖKULL No. 69, 2019 
Nikkola et al.

\section{Melt inclusions in olivine}

Representative compositions of melt inclusions in the Brattaskjól and Hvammsmúli olivine macrocrysts are shown in Table 1. At Brattaskjól, the melt inclusions in $\mathrm{Fo}_{<80.9-87.0}$ olivine macrocrysts correspond to mildly alkaline basalt $(1-3 \mathrm{wt} \%$ normative nepheline $)$ with $\mathrm{Mg} \#_{\text {melt }}\left(\mathrm{Mg} \#_{\text {melt }}=\right.$ molar $\left.100 \mathrm{Mg} /\left(\mathrm{Mg}+0.9 \mathrm{Fe}_{\text {tot }}\right)\right)$ of $56.1-68.5$, whereas the four melt inclusions in more primitive $\mathrm{Fo}_{87.9-88.6}$ olivines are silica saturated with low $\mathrm{FeO}_{t o t}$ and Mg\# melt of 68.8-73.0. Most of the homogenized Brattaskjól melt inclusions are in equilibrium with their host olivine $\left(K d_{O l-L i q}^{M g-F e}=0.30 \pm 0.3\right.$, Toplis 2005 ) and do not require post-entrapment crystallization (PEC) correction. For those melt inclusions that require it, a PEC correction of $1-6 \mathrm{wt} \%$ was made using the Petrolog software of Danyushevsky and Pletchov (2011). For these calculations, $\mathrm{FeO}^{*}$ ( $\mathrm{FeO}$ content before post-entrapment crystallisation and diffusion) of the melt inclusions was derived from the relationship of $\mathrm{Fo}$ in olivine and $\mathrm{FeO}$ in melt in suitable Eyjafjallajökull magmas (this study and Moune et al., 2012). The melt inclusions in olivines from Hvammsmúli often exhibit crystals, even after heating to $1240^{\circ} \mathrm{C}$, and it was thus not possible to perform proper PEC and diffusion correction for them. In addition, all Hvammsmúli melt inclusions have so low $\mathrm{FeO}_{t o t}$ in relation to their high $\mathrm{Mg}_{\text {melt }}$ that they are unlikely to represent any reasonable near-primary parental melt. Most likely, these melt inclusions have been modified by post-entrapment olivine crystallization and solid-state diffusion of elements from their host olivine (see Danyushevsky et al., 2000). For additional Hvammsmúli melt inclusion data, see Björnsson (2019).

\section{Clinopyroxene}

Clinopyroxene macrocrysts in the Brattaskjól $(\mathrm{n}=31)$ and Hvammsmúli $(\mathrm{n}=20)$ ankaramites have similar core compositions of Ca-rich augite, although only in the case of Brattaskjól, a subpopulation of magnesium-rich ( $\mathrm{Mg} \#_{c p x}$ 89.7-89.8; $\mathrm{Mg} \#_{c p x}=$ cation fraction $\mathrm{Mg} /\left(\mathrm{Mg}+\mathrm{Fe}_{t o t}\right)$ clinopyroxene was identified (Figure 4). Interestingly, as the clinopyroxene macrocrysts become more ferrous $\left(\mathrm{Mg \#} \#_{c p x}\right.$ decreases), $\mathrm{CaO}$ and $\mathrm{Al}_{2} \mathrm{O}_{3}$ contents gradually increase until $\mathrm{Mg} \#_{c p x} 84.5$, followed by a decrease in these oxides in more evolved clinopyroxene crystals (Figure $4 \mathrm{c}$ and $\mathrm{d}$ ). The enrichment in $\mathrm{CaO}$ and $\mathrm{Al}_{2} \mathrm{O}_{3}$, together with simultaneous decrease in $\mathrm{SiO}_{2}$ and no variation in $\mathrm{Na}_{2} \mathrm{O}$, points to an increase in the CaTschermak (CaTs) component (Figure 4b). The variation in $\mathrm{Na}_{2} \mathrm{O}$ is low, hence jadeite (Jd) component is unchanged against $\mathrm{Mg} \#_{c p x}$ in clinopyroxene cores (Figure 4e). In contrast, $\mathrm{TiO}_{2}$ shows negative (Figure $4 \mathrm{f}$ ) and $\mathrm{Cr}_{2} \mathrm{O}_{3}$ positive correlation with $\mathrm{Mg} \#_{c p x}$. Compared to clinopyroxene cores, the rims are typically richer in the ferrosilite (Fs) component and $\mathrm{TiO}_{2}$ and have lower Mg\#, Jd, CaTs (Figure 4) and $\mathrm{Cr}_{2} \mathrm{O}_{3}$.

Figure 4. - Efnasamsetningar klínópýroxendíla í ankaramíti frá Brattaskjóli og Hvammsmúla. Samsetningar kjarna eru meðaltal priggja efnagreininga á hverjum kjarna, en samsetningar kristalrima meðaltal tveggja til priggja greininga gerðar narri rimanum. Klínópýroxendílarnir hafa óðul með breytilega samsetningu og pessi breytileiki í samsetningu einstakra klínópýroxenkristalla er gefinn til kynna með fylltu gráu ferningunum (óbirt gögn). Svörtu örvarnar gefa til kynna áatluð áhrif af kristaldiffrun ólivíns (ol), Ca-ágíts (cpx) og plagíóklass (plg), par sem gert er ráð fyrir að $K d_{O l-L i q}^{M g-F e}=0.30$, $K d_{C p x-L i q}^{M g-F e}=0.27, D_{O l-L i q}^{C a}=0, D_{C p x-L i q}^{C a}=1.7, D_{O l-L i q}^{A l}=0$ og $D_{C p x-L i q}^{A l}=0.15-0.25(0,005$ aukning pegar hvert mól\% er fjarlag úr bráðinni til að líkja eftir hitaháðum áhrifum á dreifingu Al milli bráðar og klínópyroxens). Kristaldiffrun plagíóklass minnkar styrk $\mathrm{CaO}$ og $\mathrm{Al}_{2} \mathrm{O}_{3}$ í bráðinni en hefur ekki áhrif á $\mathrm{Mg}$-tölu $\left(\left(\mathrm{Mg \#}_{c p x}=\right.\right.$ katjónahlutfallið $100 \mathrm{Fe} /(\mathrm{Fe}+\mathrm{Mg}))$. Brotna örin er vektor sem sýnir áhrif diffrunar ólivíns og klínópýroxens í jöfnu hlutfalli. a) Klínópýroxenfjórhliðungur; $D i=$ díopsíð, $H d=$ hedenbergít, En = enstatít, Wo = wollastonít, Fs = ferrósilít; $b)$ Ca-tschermak's (CaTs) kristalpáttur á móti $\mathrm{Mg}_{c p x}$; c) CaO á móti $\mathrm{Mg} \#_{c p x}$; d) $\mathrm{Al}_{2} \mathrm{O}_{3}$ á móti $\mathrm{Mg \#}_{c p x}$; e) Jaðeít (Jd) kristalpáttur á móti $\mathrm{Mg} \#_{c p x}$; d) $\mathrm{TiO}_{2}$ á móti $\mathrm{Mg \#}_{c p x}$. 

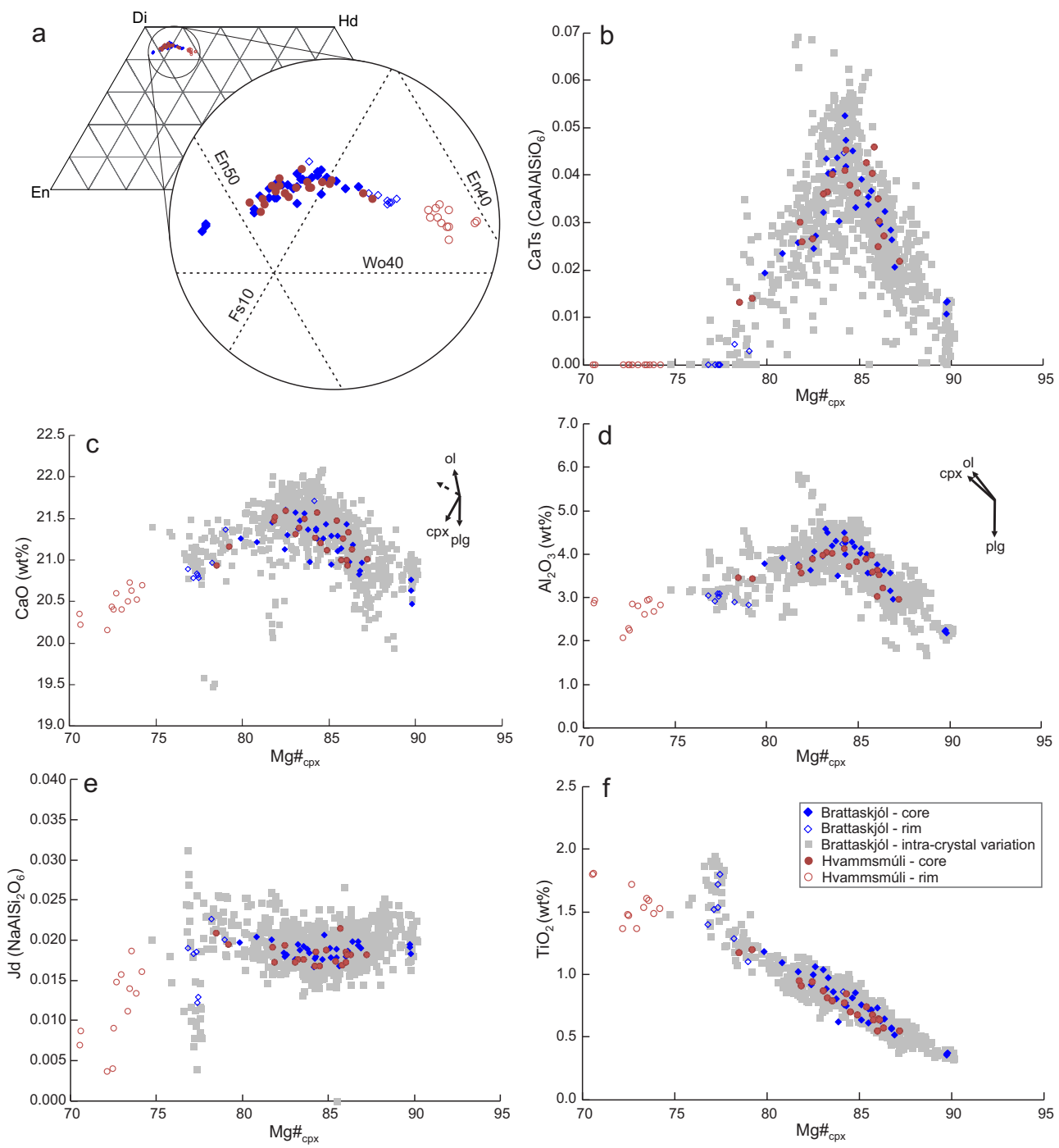

Figure 4. Clinopyroxene macrocryst compositions from the Brattaskjól and Hvammsmúli ankaramites. The core compositions are average compositions determined by three analyses from each clinopyroxene core, whereas the crystal rim compositions are averages of two to three analyses from near the crystal rims. The clinopyroxene macrocrysts include compositionally variable domains and this intra-clinopyroxene variability in all the studied crystals is illustrated with grey squares (unpublished data). Black arrows are approximated compositional vectors of olivine (ol), Ca-augite (cpx) and plagioclase (plg) fractionation, calculated assuming $K d_{O l-L i q}^{M g-F e}=0.30, K d_{C p x-L i q}^{M g-F e}=0.27, D_{O l-L i q}^{C a}=0, D_{C p x-L i q}^{C a}=1.7$, $D_{O l-L i q}^{A l}=0$ and $D_{C p x-L i q}^{A l}=0.15-0.25$ (.005 increase with every mol\% removed from melt to simulate the T-dependent partitioning of $\mathrm{Al}$ in clinopyroxene). Plg fractionation lowers $\mathrm{CaO}$ and $\mathrm{Al}_{2} \mathrm{O}_{3}$ but does not affect $\mathrm{Mg}$ number $\left(\mathrm{Mg \#} \#_{c p x}\right.$ $=$ cation ratio $\mathrm{Fe} /(\mathrm{Fe}+\mathrm{Mg})$ ). Stippled arrow is the compositional vector of ol $+\mathrm{cpx}$ fractionation in equal proportions. a) Clinopyroxene quadrilateral; $\mathrm{Di}=$ Diopside, $\mathrm{Hd}=$ Hedenbergite, En = Enstatite, Wo = Wollastonite, Fs = Ferrosilite; $\mathrm{b}$ ) Ca-Tschermak's (CaTs) component vs. $\mathrm{Mg \#}_{c p x}$; c) $\mathrm{CaO}$ vs. $\mathrm{Mg \#}_{c p x}$; d) $\mathrm{Al}_{2} \mathrm{O}_{3}$ vs. $\mathrm{Mg}_{c p x}$; e) Jadeite (Jd) component vs $\mathrm{Mg \#}_{c p x}$; d) $\mathrm{TiO}_{2}$ vs. $\mathrm{Mg} \#_{c p x}$.

JÖKULL No. 69, 2019 
Nikkola et al.

\section{DISCUSSION}

\section{Oxygen fugacity, pressure and temperature esti- mates}

We used olivine-spinel pairs to determine oxygen fugacity $\left(\mathrm{fO}_{2}\right)$ during olivine crystallization using the most recent calibration (Nikolaev et al., 2016) of the Ballhaus-Berry-Green olivine-orthopyroxenespinel oxybarometer (Ballhaus et al., 1991; Beattie, 1993). Depending on the size of the spinel grains, up to three EPMA analyses were performed, with two to three analyses from the host olivine at least $\sim 75 \mu \mathrm{m}$ from the spinel and along the same growth zone of the olivine grain. Assuming spinel-olivine co-crystallization at $3.0 \mathrm{kbar}$ and $1230^{\circ} \mathrm{C}$, these calculations yielded $\Delta \log f \mathrm{O}_{2}(\mathrm{FMQ})$ values of $0.1 \pm 0.5$ and $0.5 \pm 0.5$ for Hvammsmúli and Brattaskjól, respectively (Figure 5a). This is in line with earlier estimates of the magma oxidation state at Vestmannaeyjar (Steinthorsson 1972; Gerlach, 1980; Schipper and Moussallam, 2017) and in the Eastern Volcanic Zone of Iceland (Hartley et al., 2017).

We utilized clinopyroxene-liquid thermobarometry to estimate the temperature and pressure of clinopyroxene crystallization. This was done using the thermometer of Putirka (2008), coupled with the newly calibrated barometer of Neave and Putirka (2017). The thermobarometric calculations were carried out with an Excel workbook of Neave et al. (2019a) and by pairing the average clinopyroxene macrocryst core compositions with basaltic Eyjafjallajökull melt compositions from this study (Table 1) and the datasets of Loughlin (1995) and Moune et al. (2012). First, putative melt compositions for individual clinopyroxene crystals were selected on the basis of $\mathrm{Fe}-\mathrm{Mg}$ equilibrium, assuming $K d_{C p x-L i q}^{M g-F e}=0.27 \pm 0.6,1 \mathrm{wt} \% \mathrm{H}_{2} \mathrm{O}$, and $\mathrm{Fe}^{2+} / \sum \mathrm{Fe}$ $=0.82$ in accordance with $f \mathrm{O}_{2}=\mathrm{FMQ}+0.3$ (Kress and Carmichael, 1991). Crystallization pressures and temperatures for these putative clinopyroxene-melt pairs were solved using the Eq. 1 barometer of Neave and Putirka (2017), coupled with Eq. 33 thermometer of Putirka (2008) and by iteratively using an output of one model as an input to another. Then, we filtered these "pseudo" P-T results by only accepting the clinopyroxene-melts pairs that are in multi- component equilibrium following a method resembling that of Neave et al. (2019a). Firstly, suitable clinopyroxene-melt pairs had to be within $\pm 10 \% \mathrm{Fe}$ $\mathrm{Mg}$ equilibrium in accordance to Eq. 35 in Putirka (2008). Secondly, the measured and predicted CaTs-, EnFs- and DiHd-components in clinopyroxene had to agree within the 1SEE precision, \pm 0.03 for CaTs, \pm 0.05 for EnFs and \pm 0.06 for DiHd (mol fractions), of modelling equilibrium clinopyroxene components from the paired melts (Putirka, 1999; Mollo et al., 2013). Thirdly, we only accepted P-T estimates from the clinopyroxene-melt pairs that deviated less than $\pm 40 \%$ from $\mathrm{Ti}$ equilibrium according to the model of Hill et al. (2011). If multiple melt compositions were in equilibrium with a single clinopyroxene after this extensive equilibrium filtering, the P-T estimates were most often within the methods 1SEE precision ( $\pm 1.4 \mathrm{kbar}$ and $\pm 28^{\circ} \mathrm{C}$; Neave and Putirka, 2017; see Figure 5), and a mean of the calculated $\mathrm{P}$ and $\mathrm{T}$ was assigned for the clinopyroxene crystal. Suitable equilibrium liquids were found for nearly all clinopyroxene grains with the exception of the most magnesian (Mg\# ${ }_{c p x}$ 89.7-89.8) clinopyroxene macrocrysts indentified from Brattaskjól.

Clinopyroxene thermobarometry reveals similar crystallization temperatures and pressures for the Brattaskjól and Hvammsmúli ankaramites (Figure 5b and c). Model temperatures correlate with Mg\#, such that the most primitive clinopyroxene macrocryst with $\mathrm{Mg} \#_{c p x}>86$ record $1190^{\circ} \mathrm{C}$ and the most evolved $\mathrm{Mg \#} \#_{c p x}<81$ clinopyroxene crystal records $1120^{\circ} \mathrm{C}$ (Figure 5b). All P estimates (1.7-4.2 kbar) are within the methods precision $( \pm 1.4 \mathrm{kbar}$, Neave and Putirka, 2017) and average at $3.0 \mathrm{kbar}$, although there is a trend of increasing $\mathrm{P}$ as a function of $\mathrm{Mg}_{c p x}$ (Figure $5 \mathrm{~b}$ ). This $\mathrm{P}$ and $\mathrm{Mg \#} \#_{c p x}$ correlation is partly related to, but not fully explained by, the T dependency of the barometer. The Brattaskjól olivine-hosted melt inclusion with the lowest Mg\# melt (Ol14_mi1_2, see Table 1) was found to be a suitable equilibrium liquid for thirteen $\mathrm{Mg}_{c p x}$ 84.9-86.9 clinopyroxenes, implying crystallization conditions of $1178^{\circ} \mathrm{C}$ and $3.7 \mathrm{kbar}$ for these crystals. These are similar to the mean crystallization $\mathrm{T}$ and $\mathrm{P}$ of $1182^{\circ} \mathrm{C}$ and $3.5 \mathrm{kbar}$ derived for similar $\mathrm{Mg}_{c p x}$ 84.9-86.9 clinopyroxene 

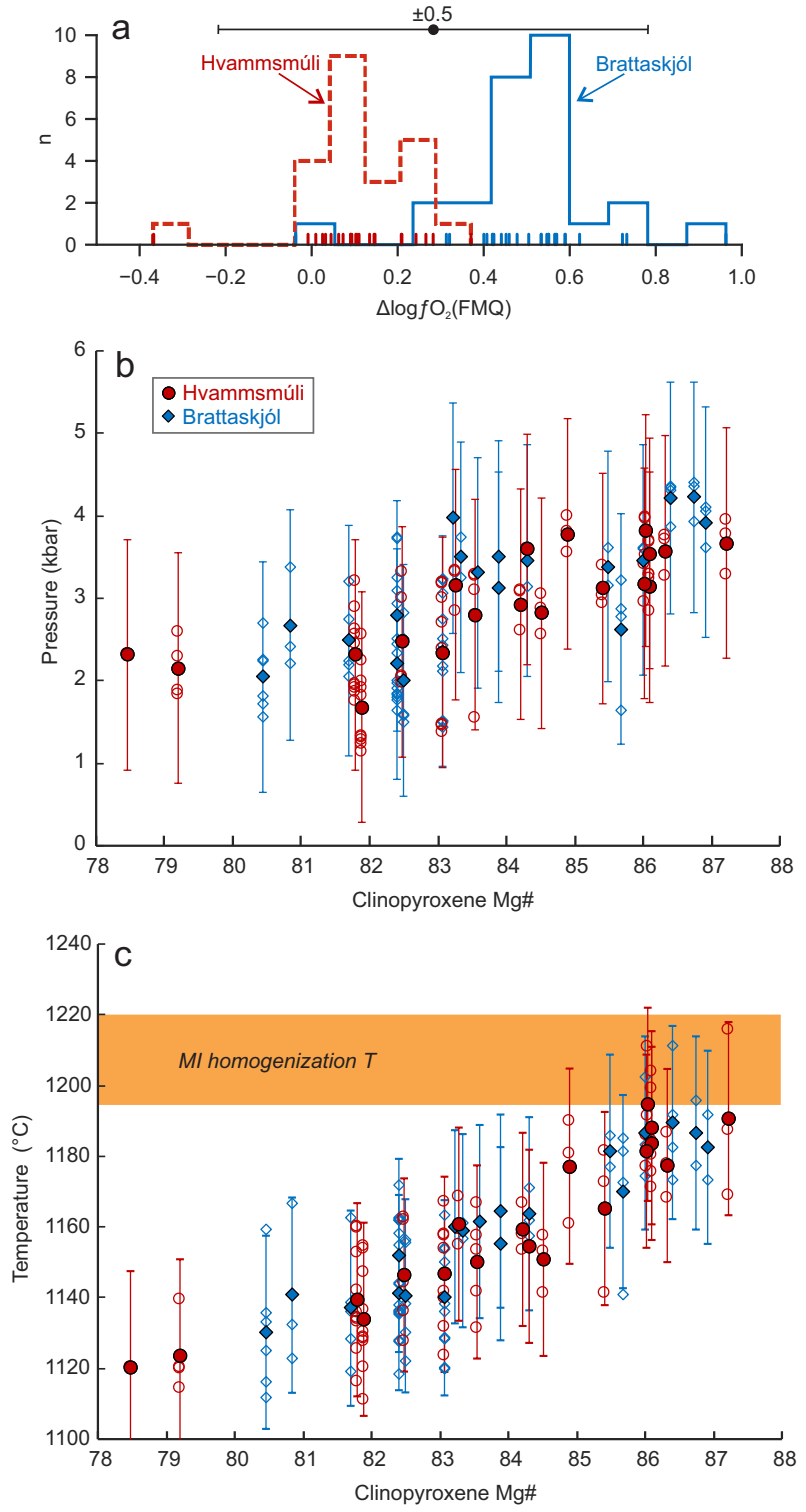

Figure 5. a) Olivine-spinel oxygen fugacity histograms for Hvammsmúli and Brattaskjól samples. b) Jd-inclinopyroxene crystallization pressures vs. clinopyroxene $\mathrm{Mg}$ number $\left(\mathrm{Mg} \#_{c p x}\right)$. The solid symbols are mean values for individual clinopyroxene grains and the hollow symbols represent values from all clinopyroxenemelt equilibrium pairs (potentially multiple $\mathrm{P}$ and $\mathrm{T}$ determinations for individual clinopyroxene crystals, see discussion). Error bars ( $\pm 1.4 \mathrm{kbar})$ correspond to the 1SEE calibration error of the barometer. c) Crystallization temperatures estimated using clinopyroxe-liquid thermometry vs. clinopyroxene $\mathrm{Mg \#}$. The solid and hollow symbols as in (b), and the orange bar shows homogenization temperatures of olivine-hosted melt inclusions (MI) from Brattaskjól. Error bars $\left( \pm 28^{\circ} \mathrm{C}\right)$ correspond to the 1SEE calibration error of the thermometer (Neave and Putirka, 2017). - a) Stuðlarit sem sýnir hlutprýsting súrefnis sem var ákvarðaður út frá ólivín-spíniljafnvagi i sýnum frá Hvammsmúla og Brattaskjóli. b) Kristöllunarprýstingur reiknaður út frá magni jaðeítkristalpátts í klínópýroxeni á móti $\mathrm{Mg}$ tölu klínópýroxens $\left(M g \#_{c p x}\right)$. Fylltu táknin eru meðalgildi fyrir einstök klínópýroxenkorn og ófylltu táknin eru gildi fyrir öll jafnvagispör af klínópýroxen og bráð (i sumum tilfellum fleiri en ein ákvörðun prýstings og hitastigs fyrir einstakan klínópýroxenkristal, sjá texta). Óvissustikurnar ( \pm 1,4 kbar) eru 1SEE kvörðunaróvissa prýstingsmaelisins. c) Kristöllunarhiti ácetlaður með klínópýroxen-bráðarhitamaeli á móti Mg\# klínópýroxens. Fylltu og ófylltu táknin eins og á (b), og gula röndin gefur til kynna hitastig pegar bráðarinnlyksur (MI) í ólivíni frá Brattaskjóli voru gerðar einsleitar. Óvissustikurnar $\left( \pm 28^{\circ} \mathrm{C}\right)$ eru 1SEE kvörðunaróvissa hitamalisins (Neave og Putirka, 2017). when pairing them with the complete Eyjafjallajökull melt dataset. This strengthens the case for using the method of pairing clinopyroxene to temporally unrelated magmas from the same volcanic system (such as Eyjafjallajökull in our case) using sufficiently robust filtering criteria of chemical equilibrium (see Neave $e t$ al., 2019a).
Complementary to the clinopyroxene-liquid P$\mathrm{T}$ estimates, we used olivine-liquid (Putirka et al., 2007) and liquid-only (Putirka, 2008) thermometry to establish the olivine crystallization temperature. Olivine-liquid thermometry according to Eq. 4 in Putirka et al. (2007) gives olivine-crystallization temperatures of $1136-1213^{\circ} \mathrm{C}$ for $\mathrm{Fo}_{80.7-88.9}$ olivine 
from Brattaskjól and Hvammsmúli. For these calculations, we paired the alkali basaltic Brattaskjól melt inclusions (Table 1) with high-precision Brattaskjól and Hvammsmúli olivine core compositions $(n=160$, Figure 2a) given that they were in Fe-Mg equilibrium ( $K d_{O l-L i q}^{M g-F e}=0.30 \pm 0.3$; Toplis, 2005) with the melt inclusions, and assumed $1 \mathrm{wt} \% \mathrm{H}_{2} \mathrm{O}$ in the melt (Moune et al., 2012). The liquid-only model temperatures for Brattaskjól alkali basalt melt inclusions (with $\mathrm{Mg \#}_{\text {melt }}$ 56-69, Table 1), in accordance with Eq. 15 in Putirka (2008) and assuming $1 \mathrm{wt} \% \mathrm{H}_{2} \mathrm{O}$ in melt, are $1155-1222^{\circ} \mathrm{C}$. The melt inclusions in $\mathrm{Fo}_{87.9-88.6}$ Brattaskjól and all Hvammsmúli olivine grains were not utilized for thermobarometric purposes, as their low $\mathrm{FeO}_{\text {tot }}$ contents suggest modification by postentrapment solid-state diffusion.

The thermobarometric calculations indicate that the macrocrysts in the Brattaskjól and Hvammsmúli ankaramites crystallized at $3 \pm 1.4 \mathrm{kbar}$ and over a $\geq 100^{\circ} \mathrm{C}$ temperature window. Assuming oceanic crustal density of $2860 \mathrm{~kg} / \mathrm{m}^{3}$ (Carlson and Herrick, 1990 ), the $3 \pm 1.4$ kbar crystallization pressure of the studied clinopyroxene crystals corresponds to a depth of $10.7 \pm 5 \mathrm{~km}$. This depth overlaps with the proposed depth of the brittle-ductile transition below Eyjafjallajökull (Hjaltadóttir et al., 2009) and is a typical preeruption residence depth of basaltic magmas in Iceland (Neave and Putirka, 2017). However, considering the high $\mathrm{Mg \#}_{c p x}$ (up to $\mathrm{Mg \#}_{87}$ ) values of the clinopyroxene crystals, the obtained mid-crustal crystallization depth is noteworthy. Due to their primitive character (magnesian whole-rock and macrocryst compositions), the Eyjafjallajökull ankaramites have been envisioned to represent magmas from the deep crust or shallow mantle (e.g., Loughlin, 1995). This, however, is not the case for the majority of the clinopyroxene grains in the Brattaskjól and Hvammsmúli ankaramites, the only potential exception being the primitive clinopyroxene crystals with $\mathrm{Mg}_{c p x} 89.7-$ 89.8 for which crystallization pressures were not determined because of the lack of suitable equilibrium liquids.

\section{Significance of olivine-hosted spinel inclusions}

The spinel inclusions in the Brattaskjól and Hvammsmúli olivine macrocrysts have higher $\mathrm{Cr} \#$ and $\mathrm{TiO}_{2}$ than hitherto published for chromian spinels from Iceland (Thy, 1983; Sigurdsson et al., 2000; Matthews et al., 2016; Spice et al., 2016) and their $\mathrm{Al}_{2} \mathrm{O}_{3}$ content is low (Figure 3). According to Kamenetsky (2001), spinel $\mathrm{TiO}_{2}$ and $\mathrm{Al}_{2} \mathrm{O}_{3}$ correlate well with the host-magma composition; therefore, spinel compositions likely reflect the nature of the parental magma. We have a poor control on the magma at depth from which these spinels crystallized, yet Eyjafjallajökull magmas are generally mildly alkaline with relatively low $\mathrm{Al}_{2} \mathrm{O}_{3}$ and high $\mathrm{TiO}_{2}$. Spinels with high $\mathrm{Cr} \#$ and $\mathrm{TiO}_{2}$ and low $\mathrm{Al}_{2} \mathrm{O}_{3}$ are typical for oceanic (OIB) and Large Igneous Province (LIP) basalts, in contrast to mid-ocean ridge basalts (MORB). In the classification of Kamenetsky (2001), the Brattaskjól and Hvammsmúli spinels plot in the OIB field (Figure 3c). The high $\mathrm{TiO}_{2}$ content in these spinels also discriminates them from mantle-derived spinels that typically have $<0.2 \mathrm{wt} \% \mathrm{TiO}_{2}$ (Kamenetsky, 2001). The $\mathrm{Al}_{2} \mathrm{O}_{3}$-poor and $\mathrm{TiO}_{2}$-enriched nature of the spinels suggests that the parental melts of the ankaramites were produced by low-degree melting of deep and enriched mantle sources, in accordance with the olivine minor and trace element chemistry (see Nikkola et al., 2019).

\section{Insights into magmatic time scales from olivine zonation}

The wide compositional zonation in the Hvammsmúli olivine macrocrysts, coarse groundmass, and the fact that both clinopyroxene and olivine macrocrysts enclose groundmass minerals around them (Figure 1c) indicate an extended cooling and crystallization history for the Hvammsmúli ankaramite. In addition, the low $\mathrm{FeO}$ and $\mathrm{MgO}$ contents in the Hvammsmúli melt inclusions suggest transfer of these elements to olivine by post-entrapment solid-state diffusion during an extended stay of the olivine crystals at magmatic conditions. According to Loughlin (1995), the Hvammsmúli ankaramite outcrop is likely an eroded lava lake, which is consistent with the diffusive reequilibration of melt inclusions and the wide compositional zonation in olivine macrocryst. It is possible that the bulk of the diffusive re-equilibration in Hvammsmúli macrocrysts took place when they resided in the postulated lava lake. 
Regarding the Brattaskjól olivine zonation, the most plausible explanation for the detected steps and changes in the slope of the Fe-Mg zoning patterns in the $\mathrm{Fo}_{>85.4}$ olivine grains (Figure $2 \mathrm{~b}$ ) is a combination of solid-state diffusion and episodes of olivine growth from an evolving host liquid. The rim-growth events in the normally zoned olivine macrocrysts may have been caused by step-like ascent of the olivinecarrying host liquid, episodic changes in the hostliquid composition, infiltration of liquid into the system (i.e., magma mixing), or related to movement of olivine macrocrysts within a magmatic system with temperature gradients (see Pankhurst et al., 2018).

The high-Fo bands in the rims of the complex reverse zoned Brattaskjól olivine macrocrysts indicate mixing between an olivine rim forming primitive melt and the more evolved olivine cores with $\mathrm{Fo}_{80-84.4}$. Below, we refer to these high-Fo bands in the olivine macrocryst rims as 'mixing plateaus'. Although the Fo content in the mixing plateaus varies, three olivine crystals show mixing plateaus with $\mathrm{Fo}_{85.4}$ composition (Figure 6a, b and d), and the lowest Fo mixing plateaus are in-fact not compositional plateaus but appear as sharp high-Fo tips in the analytical traverses (Figure $6 \mathrm{c}$ and e). This, along with the fact that all $\mathrm{Fo}_{<84.4}$ olivine macrocrysts have complex reverse zoned rims, implies that all the mixing plateaus near olivine rims may have had an original composition of $\mathrm{Fo}_{85.4}$ and the Fo content in some of the mixing plateaus has later degreased in response to partial diffusive equilibration with the carrier melt.

We suggest that these $\mathrm{Fo}_{85.4}$ mixing plateaus formed during a magmatic recharge event in which a melt (with $\mathrm{Mg \#}_{\text {melt }}$ of $\sim 63$ in equilibrium with $\mathrm{Fo}_{85.4}$ olivine; Toplis, 2005) intruded an olivine-bearing crystal mush. We propose this "magma-recharge model" as (i) it offers a simple explanation why the $\mathrm{Fo}_{<84.4}$ olivine grains are consistently reverse zoned, (ii) the large amount ( $\sim 30 \mathrm{vol} \%)$ of compositionally variable macrocrysts in the Brattaskjól ankaramite suggests a cumulative origin for the macrocrysts, and (iii) mixing of magmas and crystal mushes is common in Icelandic magmatic systems (Halldorsson et al., 2008; Neave et al., 2013; Halldórsson et al., 2018). In particular, the consistent change from com- plex reverse to normally zoned olivine at $\mathrm{Fo}_{84.4-85.4}$ (Figure 2a), and the varying offset in Fo content (1$3 \mathrm{~mol} \%$ ) between mixing plateaus and crystal cores, support a magma-recharge origin for the complex reverse zonation in olivine macrocrysts. Alternatively, the complex reverse zoned olivine macrocrysts could have been formed during their movement in a crustal intrusion with temperature gradients (cf. Pankhurst $e t$ al., 2018). Considering the low number of analysed crystals, our data cannot disprove, but neither particularly support, this mode of formation.

Assuming that our hypothesis of the magma recharge origin for the complex reverse zoned crystals is valid, we can utilize diffusion modelling (Costa et al., 2008; Zhang and Cherniak, 2010) of the chemical re-equilibration in the $\mathrm{Fe}-\mathrm{Mg}$ profiles (e.g., Figure $2 \mathrm{~d}$ ) to constrain the time frame within which the Brattaskjól complex reverse zoned olivines cooled after the recharge event. We did this by using the finite difference diffusion code of Kahl et al. (2015) that follows the procedures outlined in Costa and Chakraborty (2004) and Costa et al. (2008), with $\mathrm{Fe}-\mathrm{Mg}$ inter-diffusion coefficients of Dohmen et al. (2007) and Dohmen and Chakrabortny (2007). As the pre-diffusion initial state in our model crystals, we assumed the measured Fo contents in olivine cores, and a variably thick $(9-26 \mu \mathrm{m}) \mathrm{Fo}_{85.4}$ mixing plateau for the olivine crystals (stippled lines in Figure 6). We only modelled the time of diffusive re-equilibration between the mixing plateau and olivine-core, not between the mixing plateau and the outer crystal rim, because the outermost rims have likely been formed, at least partly, by crystallization from cooling and evolving host-magma after the magma recharge, not by solid-state diffusive re-equilibriation. Some latestage crystallization in the outermost macrocryst rims is to be expected considering the crystalline groundmass (Figure 1b) and as the macrocrysts are hosted by a comparatively slowly cooled lava.

In diffusion modelling, we used a $f \mathrm{O}_{2}$ of $\mathrm{FMQ}+0.5$, temperature of $1170^{\circ} \mathrm{C}$ and pressure of $3.0 \mathrm{kbar}$, corresponding to the mean conditions of clinopyroxene crystallization in the Brattaskjól ankaramite (Figure 5). Varying the $f \mathrm{O}_{2}$ and pressure has only a minor effect on the model results (e.g., 
Nikkola et al.
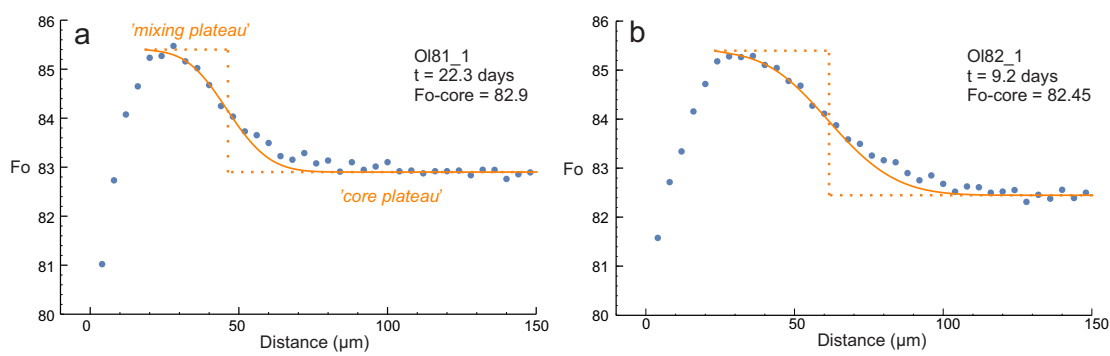

Figure 6. a-g)Fe-Mg zonation in the seven complex reverse zoned olivine macrocrysts used for dif-
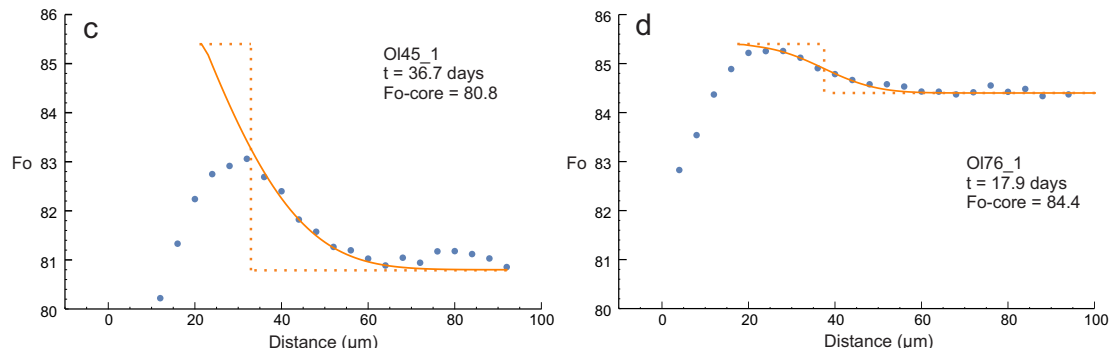
fusion modelling. The blue dots show the measured forsterite $(\mathrm{Fo})$ content near the olivine rims, the orange stippled line is the assumed initial olivine composition, and the orange curve is the calculated end result of diffusive re-equilibration after time
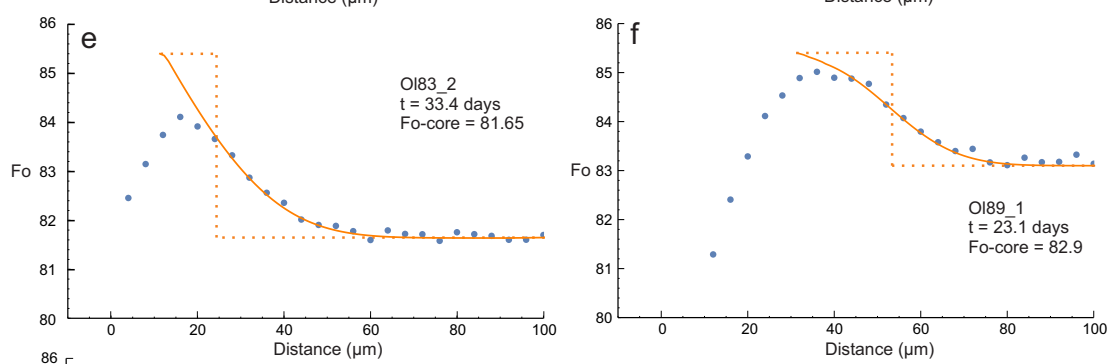

(t). - a-g) Fe-Mg-beltun í sjö ólivíndílum með flókna öfuga beltun og notaðir voru við líkanreikninga efnasveimis. Bláu punktarnir sýna maelt forsterítgildi (Fo) narri rimum ólivíns. Gula brotalinan á hverri mynd er ácetluð samsetning ólivíns í upphafi líkanreiknings og heila gula línan er reiknuð samsetning af völdum efnasveimis eftir tíma $t$.

Kahl et al., 2015); however, the timescales are sensitive to the selected model temperature. Considering the primitive nature of the Brattaskjól ankaramite, we surmise that $1170^{\circ} \mathrm{C}$ is fair, although conservative (potentially low) estimate of the diffusion $\mathrm{T}$ (see Figure 5). We prefer a lower model temperature to avoid underestimating the diffusion time scales, because, irrespective of the model conditions, the resulting diffusion timescales are the maximum time scales of subsurface storage and ascent (after magmatic recharge) as the crystals are hosted by a lava flow. Lava flow fields insulate themselves effectively (e.g., Hon et al., 1994; Self et al., 1998; Harris and Rowland, 2009) and hence lava-hosted olivine crystals may remain at high but gradually decreasing temperature for weeks to months after eruption. We cannot separate diffusion in a lava flow/lava lake and diffusion occurring at depth during subsurface ascent; this is the caveat of working with crystalline lava samples instead of tephra. 
The diffusion modelling gives diffusion time scales in the range 9-37 days (Figure 6). This time frame does not reflect the speed of the ankaramite magma ascent directly, because of the unknown olivine residence time in the lava and the fact that the timing of the magmatic recharge (forming the reverse zoned high-Fo rims) does not necessarily coincide with the beginning of the magma ascent. The magmatic recharge to the crystal mush did not necessarily act as the eruption trigger and may have occurred considerably earlier than agitation and upheaval of the olivine (and clinopyroxene) crystals (see Rae et al., 2016). Nevertheless, as the unknown time of diffusion at the surface and the potential time-delay between magmatic recharge and crystal lift both lengthen the diffusion time, our 9-37-day estimate for diffusive reequilibration can be viewed as a likely maximum time that elapsed from crystal mush disaggregation to eruption. The 9-37-day range may reflect varying olivine residence times in a magma ascent conduit or surficial lava-feeding system after the magmatic recharge event, or be due to olivine sectioning and anisotropy effects (Shea et al., 2015).

\section{Moderate-pressure co-crystallization of primitive clinopyroxene and olivine}

The Brattaskjól and Hvammsmúli ankaramites have abundant olivine and clinopyroxene macrocrysts and only minor plagioclase macrocrysts, $\mathrm{Mg} \#_{c p x}$ of clinopyroxene being as high as 90. This and the compositional variation in clinopyroxene cores suggest olivine- and clinopyroxene-dominated fractionation and a late arrival of plagioclase on the liquidus. Specifically, $\mathrm{Ca}$ and $\mathrm{Al}$ enrichment with decreasing magnesium number in clinopyroxene grains with $\mathrm{Mg \#}{ }_{c p x}$ 84.5-90.0 suggests fractionation of olivine and clinopyroxene in approximately equal amounts, and the decrease in $\mathrm{Ca}$ and $\mathrm{Al}$, which indicates simultaneous plagioclase fractionation from the host melt, is only seen in clinopyroxene grains with $\mathrm{Mg \#} \#_{c p x}<84.5$ (Figure 4c and d). Variation in crystallization conditions ( $\mathrm{T}$ and $\mathrm{P}$ ) or disequilibrium crystallization processes are unlikely to explain this compositional variation because of the unchanged Jd content in clinopyroxene cores (Figure 4e), which should be dependent on pressure, temperature and crystal- lization rate (e.g., Mollo et al., 2010; Hammer et al., 2016; Welsch et al., 2016; Ubide et al., 2019). Moreover, rapid disequilibrium crystallization is expected to produce anti-correlation between $\mathrm{Ca}$ and $\mathrm{Al}$ (Mollo et al. 2010), contrary to what is seen in our clinopyroxene data (Figures $4 \mathrm{c}$ and $\mathrm{d}$ ).

MORB melts typically crystallize in the sequence of olivine $( \pm$ spinel $) \rightarrow$ olivine + plagioclase $\rightarrow$ olivine + plagioclase + clinopyroxene, leaving behind troctolitic or gabbroic cumulates, not wehrlite cumulates, such as in the case of the Brattaskjól and Hvammsmúli ankaramites. In addition, due to the late arrival of clinopyroxene as a crystallizing phase, the most primitive clinopyroxene produced in MORB crystallization experiments typically has $\mathrm{Mg \#}_{c p x}$ of 83 (Grove and Bryan, 1983; Tormey et al., 1987; Yang et al., 1996), not $\mathrm{Mg \#}_{c p x} 90$ like in Brattaskjól ankaramite. Geochemical trends indicative of clinopyroxene fractionation before plagioclase have been noted from lavas in SEVZ and other parts of Iceland (Furman et al., 1991; Thy, 1991a; Maclennan et al., 2001; Mattsson and Oskarsson, 2005), and some Iceland lavas do host high-Mg\# clinopyroxene (up to $\mathrm{Mg} \#_{c p x} 92$ in Borgarhraun lava, Winpenny and Maclennan 2011). In this regard, our findings are in line with earlier studies. Anyhow, clinopyroxene fractionation from primitive SEVZ lavas has usually been regarded as indicative of high ( $>8 \mathrm{kbar}$ ) crystallization pressures near Moho or at upper mantle depths (Furman et al., 1991; Thy, 1991a, b; Mattsson and Oskarsson, 2005), as the stability of clinopyroxene increases with pressure (Presnall et al., 1978, 2002; Stolper, 1980). The calculated $3.0 \pm 1.4$ kbar crystallization pressures for the primitive Brattaskjól and Hvammsmúli clinopyroxene macrocrysts (up to $\mathrm{Mg \#}_{c p x} 87$ ) contradicts this contention and suggest that the mildly alkaline SEVZ magmas crystallized clinopyroxene and olivine before plagioclase at depths as shallow as in the mid-crust. This inference is supported by, and is in line with, recent experimental work that shows that "enriched end-member" (Shorttle and Maclennan, 2011) Iceland tholeiite melt crystallized clinopyroxene before plagioclase at $3 \mathrm{kbar}$ (Neave et al., $2019 b)$. Elevated $\mathrm{H}_{2} \mathrm{O}$ in primitive SEVZ magmas (Thy, 1991a; Moune et al., 2012) and low amounts of 
plagioclase-forming elements $(\mathrm{Ca}$ and $\mathrm{Al}$; see Neave et al. 2019b) are the likely factors stabilizing olivine +clinopyroxene co-crystallization in magmatic storage zones below SEVZ.

\section{PRE-ERUPTIVE CRYSTAL STORAGE AND DIFFERENTIATION}

High-Mg macrocrysts are often assumed to have crystallized deep in the Earth's crust or in the upper mantle as they represent the first crystallizing phases from mantle melts. Our data indicate mid-crustal crystallization conditions $(3.0 \pm 1.4 \mathrm{kbar}, 10.7 \pm 5 \mathrm{~km})$ at a moderate oxygen fugacity for most clinopyroxene macrocrysts in the Hvammsmúli and Brattaskjól ankaramites. The degree of diffusive relaxation in Brattaskjól olivine macrocrysts indicates diffusion times in the range of 9-37 days, which we interpret as the maximum time elapsed from crystal mush disaggregation to eruption. Clinopyroxene composition trends suggest fractionation of olivine and clinopyroxene until late in the crystallization sequence, and as such, the Hvammsmúli and Brattaskjól ankaramites likely represent magmas that incorporated wehrlite or plagioclase-wehrlite crystal mushes in the mid-crust on their way to the surface. Formation of a wehrlitic cumulus assemblage by fractional crystallization at mid-crustal pressure is possible, given that the primitive parental melt is sufficiently rich in $\mathrm{H}_{2} \mathrm{O}$ and poor in $\mathrm{Ca}$ and $\mathrm{Al}$. Our findings are in line with the earlier propositions of olivine and clinopyroxene co-crystallization from primitive SEVZ magmas, although we propose that this occurs as shallow as in the mid-crust.

\section{Acknowledgements}

This work was funded by Nordic Volcanological Centre and Icelandic Research Fund doctoral student grant (185267-051). We thank Atli Hjartarson for the aid in sample preparation and Jussi S. Heinonen for discussions. Eero Hanski delivered a useful review of an early version of the manuscript.

\section{ÁGRIP}

Skilningur á hegðun eldfjallakerfa hvað varðar innskota- og eldgosavirkni takmarkast af pví hve skammt er síðan eftirlit með eldfjöllum hófst. Til að greina hvaða skilyrði ríkja í kvikugeymum undir eldfjöllum á Suðurlandi höfum við greint efnasamsetningu steinda, beltun í steindum og efnasamsetningu bráđarinnlyksna í tveimur ankaramítmyndunum í Eyjafjöllum, sem kenndar eru við Brattaskjól og Hvammsmúla. Pessar tvær myndanir eru ríkar af dílum með fjölbreytilega samsetningu. Par á meðal er magnesínríkasta ólivín ( $\left.\mathrm{Fo}_{88-90}\right)$ og klínópýroxen $\left(\mathrm{Mg \#} \#_{c p x 89,8}\right)$ sem pekkt er frá Eyjafjallajökli. Auk pess hafa spínilinnlyksur í ólivíni hátt $\mathrm{Cr}_{s p l}(52-80)$, hátt magn $\mathrm{TiO}_{2}$ (1-3\%) og lágt magn $\mathrm{Al}_{2} \mathrm{O}_{3}(8-22 \%)$ í samanburði við dæmigerða íslenska krómspínla. Spínil-ólivín súrefnisprýstingsmælirinn gefur miðlungs háan hlutprýsting súrefnis við kristöllun, eða $\Delta \operatorname{logFMQ} 0-0,5$, og hitastigs-prýsingsmælir byggður á efnajafnvægi klínópýroxens og bráđar gefur til kynna kristöllun við prýsting sem ríkir í miðri jarðskorpunni (1,7-4,2 kbar, að meðaltali 3,0土1,4 kbar) og $1120-1195^{\circ} \mathrm{C}$ hita. Fyrir bráðarinnlyksur með Mg\# melt 56,1-68,5 gefur hitamælir sem byggir á samsetningu bráðar $1155-1222^{\circ} \mathrm{C}$ kristöllunarhita, en ólivín-bráđarhitamælir fyrir ólivín með samsetninguna $\mathrm{Fo}_{80,7-88,9}$ gefur $1136-1213^{\circ} \mathrm{C}$. Líkanreikningar á efnasveimi í beltuðu ólivíni benda til að dílar frá Brattaskjóli hafi farið af stað og flust til yfirborðs frá geymslurými í miðri skorpunni innan fárra vikna (innan 9-37 daga). Leitni í samsetningu klínópýroxendíla og pað hversu sjaldgæfir plagíóklasdílar eru gefur til kynna að kótektískt fasafylki í miðskorpunni hafi verið ólivín ásamt klínópýroxeni og að plagíóklas hafi komið seinna til sögunnar. Niðurstaðan er að dílafarmur ankaramítsins í Brattaskjóli og Hvammsmúla hafi verið að uppruna kristalríkur massi í miðskorpunni með steindafylki wehrlíts og plagíóklaswehrlíts sem kristallaðist á víðu hitastigsbili og varð síðan fyrir röskun.

\section{REFERENCES}

Ballhaus, C., R.F. Berry and D.H. Green 1991. High pressure experimental calibration of the olivineorthopyroxene-spinel oxygen geobarometer: implications for the oxidation state of the upper mantle. Contrib. Mineral Petrol. 107, 27-40

Batanova, V.G., A. V. Sobolevand and D. V. Kuzmin 
2015. Trace element analysis of olivine: High precision analytical method for JEOL JXA-8230 electron probe microanalyser. Chem. Geol. 419, 149-157. https://doi.org/10.1016/j.chemgeo.2015.10.042

Beattie, P. 1993. Olivine-melt and orthopyroxene-melt equilibria. Contrib. Mineral Petrol. 115, 103-111. https://doi.org/10.1007/BF00712982

Björnsson, G. 2019. High-temperature experimental study of olivine-hosted melt inclusions from Hvammsnúpur. BSc thesis, Faculty of Earth Science, University of Iceland, $43 \mathrm{pp}$.

Brandsdóttir, B. and W. H. Menke 2008. The seismic structure of Iceland. Jökull 58, 17-34.

Carlson, R. L. and Herrick, C. N. 1990. Densities and porosities in the oceanic crust and their variations with depth and age. J. Geophys. Res. 95, 9153. https://doi.org/10.1029/JB095iB06p09153

Chauvel, C. and C. Hémond 2000. Melting of a complete section of recycled oceanic crust: Trace element and $\mathrm{Pb}$ isotopic evidence from Iceland. Geochem. Geophys. Geosys. 1, 1-22. https://doi.org/10.1029/1999GC000002

Costa, F. and S. Chakraborty 2004. Decadal time gaps between mafic intrusion and silicic eruption obtained from chemical zoning patterns in olivine. Earth Planet. Sci. Lett. 227, 517-530. https://doi.org/10.1016/j.eps1.2004.08.011

Costa, F., R. Dohmen and S. Chakraborty 2008. Time scales of magmatic processes from modelling the zoning patterns of crystals. Rev. Mineral. Geochem. 69, 545-594. https://doi.org/10.2138/rmg.2008.69.14

Danyushevsky, L. V., F. N. Della-Pasqua and S. Sokolov 2000. Re-equilibration of melt inclusions trapped by magnesian olivine phenocrysts from subduction-related magmas: Petrological implications. Contrib. Mineral. Petrol. 138, 68-83. https://doi.org/10.1007/PL00007664

Danyushevsky, L. V. and P. Plechov 2011. Petrolog3: Integrated software for modeling crystallization processes. Geochem. Geophys. Geosys. 12, 1-32. https://doi.org/10.1029/2011GC003516

Dohmen, R., H.-W. Becker and S. Chakraborty 2007. $\mathrm{Fe}-\mathrm{Mg}$ diffusion in olivine I: experimental determination between 700 and $1,200^{\circ} \mathrm{C}$ as a function of composition, crystal orientation and oxygen fugacity. Phys. Chem. Miner. 34, 389-407. https://doi.org/10.1007/s00269-007-0157-7

Dohmen, R. and S. Chakraborty 2007. Fe-Mg diffusion in olivine II: point defect chemistry, change of diffusion mechanisms and a model for calculation of diffusion coefficients in natural olivine. Phys. Chem. Miner. 34, 409-430. https://doi.org/10.1007/s00269-007-0158-6

Flóvenz, Ó. G. and K. Saemundsson 1993. Heat flow and geothermal processes in Iceland. Tectonophysics 225, 123-138. https://doi.org/10.1016/00401951(93)90253-G

Furman, T., Frey, F. A. and Park, K. H. 1991. Chemical constraints on the petrogenesis of mildly alkaline lavas from Vestmannaeyjar, Iceland: the Eldfell (1973) and Surtsey (1963-1967) eruptions. Contrib. Mineral Petrol. 109, 19-37. https://doi.org/10.1007/BF00687198

Gerlach, T. M. 1980. Evaluation of volcanic gas analysis from Surtsey volcano, Iceland 19641967. J. Volcanol. Geotherm. Res. 8, 191-198. https://doi.org/10.1016/0377-0273(80)90104-3

Grove, T.L. and W.B. Bryan 1983. Fractionation of pyroxene-phyric MORB at low pressure: An experimental study. Contrib. Mineral. Petrol. 84, 293-309. https://doi.org/10.1007/BF01160283

Halldórsson, S. A., E. Bali, M.E. Hartley et al. 2018. Petrology and geochemistry of the 2014-2015 Holuhraun eruption, central Iceland: compositional and mineralogical characteristics, temporal variability and magma storage. Contrib. Mineral. Petrol. 173, 1-25. https://doi.org/10.1007/s00410-018-1487-9

Halldorsson, S. A., N. Oskarsson, K. Gronvold et al. 2008. Isotopic-heterogeneity of the Thjorsa lava-Implications for mantle sources and crustal processes within the Eastern Rift Zone, Iceland. Chem. Geol. 255, 305-316. https://doi.org/10.1016/j.chemgeo.2008.06.050

Hammer, J., S. Jacob, B. Welsch et al. 2016. Clinopyroxene in postshield Haleakala ankaramite: 1. Efficacy of thermobarometry. Contrib. Mineral. Petrol. 171, 1-23. https://doi.org/10.1007/s00410-015-1212-x

Harris, A. J. L. and S. K. Rowland 2009. Effusion rate controls on lava flow length and the role of heat loss: a review. In: Studies in Volcanology: The Legacy of George Walker. The Geological Society of London on behalf of The International Association of Volcanology and Chemistry of the Earth's Interior, 33-51.

Hartley, M.E., O. Shorttle, J. Maclennan et al. 2017. Olivine-hosted melt inclusions as an archive of redox heterogeneity in magmatic systems. Earth Planet. Sci. Lett. 479, 192-205. https://doi.org/10.1016/j.epsl.2017.09.029 
Nikkola et al.

Hémond, C., N. T. Arndt, U. Lichtenstein et al. 1993. The heterogeneous Iceland plume: $\mathrm{Nd}-\mathrm{Sr}-\mathrm{O}$ isotopes and trace element constraints. J. Geophys. Res. 98, 1583315850. https://doi.org/10.1029/93JB01093

Hill, E., J. D. Blundy and B. J. Wood 2011. Clinopyroxenemelt trace element partitioning and the development of a predictive model for HFSE and Sc. Contrib. Mineral. Petrol. 161, 423-438. https://doi.org/10.1007/s00410010-0540-0

Hjaltadóttir, S., K. S. Vogfjörð and R. Slunga 2009. Seismic signs of magma pathways through the crust in the Eyjafjallajökull volcano, south Iceland. Rep. 200913, Icel. Meteorol. Office, Reykjavík, 25 pp.

Hon, K., J. Kauhikau, R. Denlinger and K. Mackay 1994. Emplacement and inflation of pahoehoe sheet flows: Observations and measurements of active lava flows on Kilauea Volcano, Hawaii. Geol. Soc. Am. Bull. 106, 351-370. https://doi.org/10.1130/00167606(1994)106<0351:EAIOPS>2.3.CO;2

Jakobsson, S.P. 1972. Chemistry and distribution pattern of recent basaltic rocks in Iceland. Lithos 5, 365-386. https://doi.org/10.1016/0024-4937(72)90090-4

Kahl, M., S. Chakraborty, M. Pompilio and F. Costa 2015. Constraints on the nature and evolution of the magma plumbing system of Mt. Etna volcano (1991-2008) from a combined thermodynamic and kinetic modelling of the compositional record of minerals. J. Petrol. 56, 2025-2068. https://doi.org/10.1093/petrology/egv063

Kahl, M., M. Viccaro, T. Ubide et al. 2017. A branched magma feeder system during the 1669 eruption of Mt Etna: Evidence from a time-integrated study of zoned olivine phenocryst populations. J. Petrol. 58, 443-472. https://doi.org/10.1093/petrology/egx022

Kamenetsky, V.S. 2001. Factors controlling chemistry of magmatic spinel: an empirical study of associated olivine, $\mathrm{Cr}$-spinel and melt Inclusions from primitive rocks. J. Petrol. 42, 655-671. https://doi.org/10.1093/petrology/42.4.655

Keiding, J.K. and O. Sigmarsson 2012. Geothermobarometry of the 2010 Eyjafjallajökull eruption: New constraints on Icelandic magma plumbing systems. J. Geophys. Res. Solid Earth 117, 1-15. https://doi.org/10.1029/2011JB008829

Kokfelt, T.F., K. Hoernle, F. Hauff et al. 2006. Combined trace element and $\mathrm{Pb}-\mathrm{Nd}-\mathrm{Sr}-\mathrm{O}$ isotope evidence for recycled oceanic crust (upper and lower) in the Iceland mantle plume. J. Petrol. 47, 1705-1749. https://doi.org/10.1093/petrology/eg1025
Kress, V.C. and I.S.E. Carmichael 1991. The compressibility of silicate liquids containing $\mathrm{Fe}^{2} \mathrm{O}^{3}$ and the effect of composition, temperature, oxygen fugacity and pressure on their redox states. Contrib. Mineral. Petrol. 108, 82-92. https://doi.org/10.1007/BF00307328

Kristjánsson, L., H. Jóhannesson, J. Eiríksson and A. I. Gudmundsson 1988. Brunhes-Matuyama paleomagnetism in three lava sections in Iceland. Can. J. Earth Sci. https://doi.org/10.1139/e88-024

Laeger, K., M. Petrelli, D. Andronico et al. 2017. High-resolution geochemistry of volcanic ash highlights complex magma dynamics during the Eyjafjallajökull 2010 eruption. Am. Mineral. 102, 11731186. https://doi.org/10.2138/am-2017-5860

Loughlin, S.C. 1995. The evolution of the Eyjafjöll volcanic system, southern Iceland. $\mathrm{PhD}$ thesis, University of Durham, UK, 319 pp.

Maclennan, J., D. McKenzie, K. Grönvold and L. Slater 2001. Crustal accretion under Northern Iceland. Earth Planet. Sci. Lett. 191, 295-310. https://doi.org/10.1016/S0012-821X(01)00420-4

Martin, E., J.L. Paquette, V. Bosse et al. 2011. Geodynamics of rift-plume interaction in Iceland as constrained by new 40Ar/39Ar and in situ U-Pb zircon ages. Earth Planet. Sci. Lett. 311, 28-38. https://doi.org/10.1016/j.eps1.2011.08.036

Matthews, S., O. Shorttle and J. Maclennan 2016. The temperature of the Icelandic mantle from olivine-spinel aluminum exchange thermometry. Geochem. Geophys. Geosys.https://doi.org/10.1002/2016GC006497

Mattsson, H.B. and N. Oskarsson 2005. Petrogenesis of alkaline basalts at the tip of a propagating rift: Evidence from the Heimaey volcanic centre, south Iceland. J. Volcanol. Geotherm. Res. 147, 245-267. https://doi.org/10.1016/j.jvolgeores.2005.04.004

Mollo, S., P. Del Gaudio, G. Ventura et al. 2010. Dependence of clinopyroxene composition on cooling rate in basaltic magmas: Implications for thermobarometry. Lithos 118, 302-312. https://doi.org/10.1016/j.lithos.2010.05.006

Mollo, S., K. Putirka, V. Misiti et al. 2013. A new test for equilibrium based on clinopyroxenemelt pairs: Clues on the solidification temperatures of Etnean alkaline melts at posteruptive conditions. Chem. Geol. 352, 92-100. https://doi.org/10.1016/j.chemgeo.2013.05.026 
Moune, S., O. Sigmarsson, P. Schiano et al. 2012. Melt inclusion constraints on the magma source of Eyjafjallajökull 2010 flank eruption. J. Geophys. Res. Solid Earth 117, 1-13. https://doi.org/10.1029/2011JB008718

Neave, D. A., E. Bali, G. H. Guðfinnsson et al. 2019a. Clinopyroxene-liquid equilibria and geothermobarometry in natural and experimental tholeiites: the 2014-2015 Holuhraun eruption, Iceland. J. Petrol. 60, 1653-1680. https://doi.org/10.1093/petrology/egz042

Neave, D. A., O. Namur, O. Shorttle and F. Holtz 2019b. Magmatic evolution biases basaltic records of mantle chemistry towards melts from recycled sources. Earth Planet. Sci. Lett. 520, 199-211. https://doi.org/10.1016/j.epsl.2019.06.003

Neave, D. A., E. Passmore, J. Maclennan et al. 2013. Crystal-melt relationships and the record of deep mixing and crystallization in the AD 1783 Laki eruption, Iceland. J. Petrol. 54, 1661-1690. https://doi.org/10.1093/petrology/egt027

Neave, D. A. and K.D. Putirka 2017. A new clinopyroxene-liquid barometer, and implications for magma storage pressures under Icelandic rift zones. Am. Mineral. 102, 777-794. https://doi.org/10.2138/am-2017-5968

Nikkola, P., G.H. Guðfinnsson, E. Bali et al. 2019. Signature of deep mantle melting in South Iceland olivine. Contrib. Mineral. Petrol. 174, 1-19. https://doi.org/10.1007/s00410-019-1580-8

Nikolaev, G. S., A. A. Ariskin, G. S. Barmina et al. 2016. Test of the Ballhaus-Berry-Green Ol-Opx-Sp oxybarometer and calibration of a new equation for estimating the redox state of melts saturated with olivine and spinel. Geochemistry Int. 54, 301-320. https://doi.org/10.1134/S0016702916040078

Pankhurst, M. J., D. J. Morgan, T. Thordarson and S.C. Loughlin 2018. Magmatic crystal records in time, space, and process, causatively linked with volcanic unrest. Earth Planet. Sci. Lett. 493, 231-241. https://doi.org/10.1016/j.epsl.2018.04.025

Peate, D. W., K. Breddam, J. A. Baker et al. 2010. Compositional characteristics and spatial distribution of enriched Icelandic mantle components. J. Petrol. 51, 1447-1475. https://doi.org/10.1093/petrology/egq025

Presnall, D. C., S. A. Dixon, J. R. Dixon et al. 1978. Liquidus phase relations on the join diopside-forsteriteanorthite from 1 atm to $20 \mathrm{kbar}$ : Their bearing on the generation and crystallization of basaltic magma. Contrib. Mineral. Petrol. 66, 203-220. https://doi.org/10.1007/BF00372159

Presnall, D.C., G.H. Gudfinnsson and M.J. Walter 2002. Generation of mid-ocean ridge basalts at pressures from 1 to $7 \mathrm{GPa}$. Geochim. Cosmochim. Acta 66, 2073-2090. https://doi.org/10.1016/S00167037(02)00890-6

Prior, D. J., A.P. Boyle, F. Brenker et al. 1999. The application of electron backscatter diffraction and orientation contrast imaging in the SEM to textural problems in rocks. Am. Mineral. 84, 1741-1759. https://doi.org/10.2138/am-1999-11-1204

Putirka, K. 1999. Clinopyroxene + liquid equilibria to $100 \mathrm{kbar}$ and 2450 K. Contrib. Mineral. Petrol. 135, 151-163. https://doi.org/10.1007/s004100050503

Putirka, K. D. 2008. Thermometers and barometers for volcanic systems. Rev. Mineral. Geochem. 69, 61-120. https://doi.org/10.2138/rmg.2008.69.3

Putirka, K. D., M. Perfit, F. J. Ryerson and M.G. Jackson 2007. Ambient and excess mantle temperatures, olivine thermometry, and active vs. passive upwelling. Chem. Geol. 241, 177-206. https://doi.org/10.1016/j.chemgeo.2007.01.014

Rae, A.S.P., M. Edmonds, J. Maclennan et al. 2016. Time scales of magma transport and mixing at Kîlauea Volcano, Hawai'i. Geology 44, 463-466. https://doi.org/10.1130/G37800.1

Roedder, E. 1984. Fluid Inclusions. Reviews in Mineralogy Vol. 12, Mineralogical Society of America, 644 pp.

Schipper, C.I. and Y. Moussallam 2017. Temporal redox variation in basaltic tephra from Surtsey volcano (Iceland). Bull. Volcanol. 79, 1-5. https://doi.org/10.1007/s00445-017-1156-2

Self, S., L. Keszthelyi and T. Thordarson 1998. The importance of pahoehoe. Annu. Rev. Earth Planet. Sci. 26, 81-110. https://doi.org/10.1146/annurev.earth.26.1.81

Shea, T., F. Costa, D. Krimer and J. E. Hammer 2015. Accuracy of timescales retrieved from diffusion modeling in olivine: A 3D perspective. Am. Mineral. 100, 2026-2042. https://doi.org/10.2138/am-2015-5163

Shorttle, O. and J. Maclennan 2011. Compositional trends of Icelandic basalts: Implications for shortlength scale lithological heterogeneity in mantle plumes. Geochem. Geophys. Geosys. 12, Q11008. https://doi.org/10.1029/2011GC003748

Sigmarsson, O. 1996. Short magma chamber residence time at an Icelandic volcano inferred from U-series disequilibria. Nature 382, 440-442. https://doi.org/10.1038/382440a0 
Nikkola et al.

Sigmarsson, O., I. Vlastelic, R. Andreasen et al. 2011. Remobilization of silicic intrusion by mafic magmas during the 2010 Eyjafjallajökull eruption. Solid Earth 2, 271-281. https://doi.org/10.5194/se-2-271-2011

Sigmundsson, F., S. Hreinsdóttir, A. Hooper et al. 2010. Intrusion triggering of the 2010 Eyjafjallajökull explosive eruption. Nature 468, 426-430. https://doi.org/10.1038/nature09558

Sigurdsson, I. A., S. Steinthorsson and K. Grönvold 2000. Calcium-rich melt inclusions in Cr-spinels from Borgarhraun, northern Iceland. Earth Planet. Sci. Lett. 183, 15-26. https://doi.org/10.1016/S0012821X(00)00269-7

Spice, H.E., J. G. Fitton and L. A. Kirstein 2016. Temperature fluctuation of the Iceland mantle plume through time. Geochem. Geophys. Geosys.i7. https://doi.org/10.1002/2015GC006059

Steinthórsson, S. 1964. The ankaramites of Hvammsmuli. Acta Nat. Islandica 2, 1-31.

Steinthorsson, S. 1972. The opaque mineralogy of Surtsey. Surtsey Res. Prog. Rep. 6, 152-157.

Stolper, E. 1980. A phase diagram for mid-ocean ridge basalts: Preliminary results and implications for petrogenesis. Contrib. Mineral. Petrol. 74, 13-27. https://doi.org/10.1007/BF00375485

Tarasewicz, J., B. Brandsdóttir, R. S. White et al. 2012a. Using microearthquakes to track repeated magma intrusions beneath the Eyjafjallajökull stratovolcano, Iceland. J. Geophys. Res. Solid Earth 117, 1-13. https://doi.org/10.1029/2011JB008751

Tarasewicz, J., R. S. White, A.W. Woods et al. 2012b. Magma mobilization by downward-propagating decompression of the Eyjafjallajkull volcanic plumbing system. Geophys. Res. Lett. 39, 1-5. https://doi.org/10.1029/2012GL053518

Thy, P. 1983. Spinel minerals in transitional and alkali basaltic glasses from Iceland. Contrib. Mineral. Petrol. 83, 141-149. https://doi.org/10.1007/BF00373087

Thy, P. 1991a. High and low pressure phase equilibria of a mildly alkalic lava from the 1965 Surtsey eruption: Implications for the evolution of mildly alkalic and transitional basalts in the south-eastern propagating rift zone of Iceland. Lithos 26, 253-269. https://doi.org/10.1016/0024-4937(91)90032-G
Thy, P. 1991b. High and low pressure phase equilibria of a mildly alkalic lava from the 1965 Surtsey eruption: Experimental results. Lithos 26, 223-243. https://doi.org/10.1016/0024-4937(91)90030-O

Toplis, M.J. 2005. The thermodynamics of iron and magnesium partitioning between olivine and liquid: Criteria for assessing and predicting equilibrium in natural and experimental systems. Contrib. Mineral. Petrol. 149, 22-39. https://doi.org/10.1007/s00410004-0629-4

Tormey, D. R., T.L. Grove and W.B. Bryan 1987. Experimental petrology of normal MORB near the Kane Fracture Zone: $22^{\circ}-25^{\circ} \mathrm{N}$, mid-Atlantic ridge. Contrib. Mineral. Petrol. 96, 121-139. https://doi.org/10.1007/BF00375227

Ubide, T., S. Mollo, J. Zhao et al. 2019. Sectorzoned clinopyroxene as a recorder of magma history, eruption triggers, and ascent rates. Geochim. Cosmochim. Acta 251, 265-283. https://doi.org/10.1016/j.gca.2019.02.021

Welsch, B., J. Hammer, A. Baronnet et al. 2016. Clinopyroxene in postshield Haleakala ankaramite: 2. Texture, compositional zoning and supersaturation in the magma. Contrib. Mineral. Petrol. 171, 1-19. https://doi.org/10.1007/s00410-015-1213-9

Winpenny, B. and J. Maclennan 2011. A partial record of mixing of mantle melts preserved in Icelandic phenocrysts. J. Petrol. 52, 1791-1812. https://doi.org/10.1093/petrology/egr031

Wiese, P. K. 1992. Geochemistry and geochronology of the Eyjafjöll Volcanic System. Unpubl. MSc Thesis, University of Oregon.

Wolfe, C.J., I. T. Bjarnason, J.C. VanDecar and S.C. Solomon 1997. Seismic structure of the Iceland mantle plume. Nature 385, 245-247. https://doi.org/10.1038/385245a0

Yang, H., R.J. Kinzler and T.L. Grove 1996. Experiments and models of anhydrous, basaltic olivine-plagioclase-augite saturated melts from 0.001 to 10 kbar. Contrib. Mineral. Petrol. 124, 1-18. https://doi.org/10.1007/s004100050169

Zhang, Y. and D. Cherniak 2010. Diffusion in Minerals and Melts. Rev. Mineral. Geochem. https://doi.org/10.2138/rmg.2010.72.2 